https://helda.helsinki.fi

\title{
The Conceptual History of the Welfare State in Finland
}

\section{Kettunen, Pauli Tapio}

Berghahn books

2019-01

Kettunen , P T 2019, The Conceptual History of the Welfare State in Finland . in N Edling (ed.), The Changing Meanings of the Welfare State : Histories of a Key Concept in the Nordic Countries . Berghahn books, pp. 225-275.

http://hdl.handle.net/10138/313719

acceptedVersion

Downloaded from Helda, University of Helsinki institutional repository.

This is an electronic reprint of the original article.

This reprint may differ from the original in pagination and typographic detail.

Please cite the original version. 
Final manuscript of chapter 5 in Nils Edling (ed.): Changing Meanings of the Welfare State: Histories of a Key Concept in the Nordic Countries. Berghahn Books, Oxford \& New York 2019, pp. 225-275.

\section{The Conceptual History of the Welfare State in Finland}

Pauli Kettunen

Reinhart Koselleck has taught us that one of the main characteristics of modern political concepts is their being 'temporalized'. They were shaped as a means of governing the tension between 'the space experience and the horizon of expectation' that was constitutive of the modern notions of history and politics. The concepts became 'instruments for the direction of historical movement', which was often conceptualized as development or progress. ${ }^{1}$ From our current historical perspectives, the making of the welfare state easily appears as an important phase and stream of such a 'historical movement' in the Nordic countries. However, it was actually quite late that the concept of the welfare state played any significant part in the direction of this movement. ${ }^{2}$

In Finland, after the era of the expanding welfare state, the notion of the welfare state as a creation of a joint national project has strongly emerged. Such a notion seems to be shared in Finland more widely than in other Nordic countries, especially in Sweden, where a hard struggle opened up between the Social Democrats and the right-wing parties over ownership of the history of the welfare state. ${ }^{3}$ This may seem paradoxical, as still in the early 1990s Finnish social policy researchers could, with good reason, argue that in Finland the concept of welfare state (hyvinvointivaltio) did not play as significant a role as did välfärdsstat in Sweden. ${ }^{4}$ The current 
strength of the consensual historical-political interpretation actually reflects the fact that in Finland, more so than in other Nordic countries, the making of the welfare state was a process of short-term interest conflicts and compromises, and it has been less obvious that any political force (most notably, the Social Democrats) could claim that the welfare state had been its planned political project and achievement. ${ }^{5}$

The observations of the case of Finland suggest that in any analysis of the introduction and usage of the concept of welfare state it is also important to pay attention to how the concept came to refer to past times and activities in ways not conceived of by contemporary actors.

Consequently, it is necessary to ask how they did conceive of those activities. In what follows, the analysis begins with the last question. ${ }^{6}$ How did the actors defining social problems and solutions conceive of what was later discussed as the history of the welfare state in Finland? How were 'welfare' and 'state' - notably the Swedish and Finnish equivalents of these terms included in these conceptualizations? From these questions, the discussion proceeds to the emergence of the concept of welfare state; to the criteria for the situations in which the term is used; to its range of references; and to the contested valuations associated with the term. ${ }^{7}$ Finally, political charges associated with the distinction between the welfare state and welfare society are examined. The research material consists of texts discussing social policies, including pamphlets, handbooks and textbooks written by social policy scholars, party manifestos, minutes of (Social Democratic) party congresses, government programmes and journals and newspapers, with the last-mentioned material being (in June 2017) covered until 1920 by the digitized newspaper archive of the Finnish National Library. ${ }^{8}$ 


\section{Finland as a Nordic Case}

Finland may easily qualify as the most exceptional of the five national exceptions that comprise the Nordic model. It was a latecomer to industrialization and urbanization, and it was also the Nordic latecomer in the field of social policies and industrial relations. Connections and conflicts with the Czarist and Soviet empires are a particular dimension of Finland's history, and the classbased Civil War of 1918 and the two wars against the Soviet Union (1939-40 and 1941-44) as a part of World War II had many political, not least social-political, implications. In a study on concepts and language, the Finnish exceptionality may appear especially striking, as the FinnoUgrian language spoken by the majority of the population is totally different from the IndoEuropean Scandinavian languages.

New sovereign nation states were built after the collapse of the Eastern and Central European multi-ethnic empires, and Finland was one of them. The country declared its independence after the October Revolution, in December 1917. In January 1918, the Civil War began between the socialist Reds and the bourgeois Whites, preconditioned by the international crisis and domestic class-based conflicts. It ended with the victory of the Whites in May 1918. Despite the counterrevolutionary outcome of the Civil War, however, Finland was established in the constitution of 1919 as a parliamentary republic. Again, this solution had its prerequisites in international transformations. The alliance of the White winners with the German Empire collapsed after the German Empire not only lost World War I but was also dissolved through revolution. Importantly, however, parliamentary democracy survived in Finland in the 1920s and 1930s as the form of political system, even though it was threatened and limited by right-wing pressure, especially in the early 1930s.The sustaining of democratic forms made Finland exceptional among the new nation states created after the collapse of the Eastern and Central European 
empires. In order to understand this exceptionality, it is important to recognize that Nordic political traditions had played a crucial role in the Finnish nation-building.

Sweden lost its eastern provinces in the Russo-Swedish War of 1808-9, which was part of the Napoleonic Wars, and they were reshaped as the Grand Duchy of Finland within the Russian Empire. In the nineteenth century, the Grand Duchy developed into an autonomous nation state. In the borderland of the Russian Empire, old Swedish legal and religious (Lutheran) institutions and traditions continued, utilized by and intertwined with the new Finnish nationalism that was largely compatible with the Russian imperial interest of promoting the separation of Finland from Sweden.

In the loyal Grand Duchy of Finland, the old Swedish Four-Estate (nobility, clergy, burghers, and farmers) Diet was reintroduced in 1863. Space for political debate and civic organization opened up in the 1860s. 'The people' emerged in the debates of the political elite as a target for education and 'national awakening' and as the source of political legitimacy. Conflicts tended to be shaped as struggles for the right way and privilege to speak in the name of 'the people'. This was evident in the controversies between the so-called Fennomanians and the so-called Liberals from the 1860s onwards, concerning the role of language, culture and constitution in the making of the nation, and it was also characteristic of later political conflicts concerning the right ways of defending the autonomy of Finland and the handling of social class divisions. ${ }^{9}$

The Finnish nation builders could, by means of real historical references, make use of and contribute to the development of Nordic nationalist myths. Most importantly, this concerned the idealized heritage of the free Nordic peasant that had been capable of local self-government and integrated with the state, as the peasantry had formed one of the four estates in the Swedish realm. In the late nineteenth century, the Finnish polity was shaped on the basis of this ideational 
and institutional continuity. At the same time, the idea of Norden came to play an important role in Finland as a framework for international comparison, communication and cooperation in various fields of social knowledge, and 'Nordic' became an ingredient of Finnish national identity.

On the other hand, the making of the Finnish nation and nation state in the nineteenth century occurred through the construction of a cultural identity distinct from Sweden's. This also included a change of language from Swedish to Finnish (the language of the majority of the people) by many families of the political, economic and cultural elite. A central, yet contested, part of the nation building had to do with refining the Finnish language so that it was capable of dealing with politics and sciences and of connecting the people and the educated. The coexistence of the Finnish and Swedish languages was associated with political controversies about the right way of defining and representing the nation, but it also implied policies of translation that made the structures of meaning of the two languages converge, even though the refiners of the Finnish language eagerly made use of vernacular raw materials when developing the Finnish vocabulary. At the beginning of the twenty-first century, the Swedish-speaking population comprises little more than 5 per cent of the whole population. However, in constitutional terms, Swedish is not a minority language (as are the Sámi languages); rather, Finnish and Swedish constantly have an equal status as the two official languages of the bilingual country.

The conceptual history of the Finnish welfare state is a history of välfärdsstat (Swedish) and hyvinvointivaltio (Finnish). However, this history also encompasses different layers of meaning that were embedded in linguistic modes of constructing social problems, which only later were grasped and reshaped via the concept of welfare state. ${ }^{10}$ As a particular Nordic case, Finland 
indicates that the concept of society played a significant role in discussions of social problems and solutions. Provided with a strong normative charge and frequently used as a synonym for 'state', the concept of society appears as an effective tool for how space was opened up for divergent viewpoints on the legitimacy and limits of state intervention. It was in this ideational space that 'welfare' and 'state' later became combined as a way of conceptualizing the contents and outcomes of past processes rather than as the name for a future goal.

\section{A Conceptual Confusion}

In Sweden, critics of the 'patronizing' welfare state observed in the 1980s that no clear distinction existed between 'state' (stat) and 'society' (samhälle) in the political language. Not infrequently, 'society' appeared where one might expect to see the words 'state' or 'public power'. Critics concluded that this, as they supposed, unique conceptual confusion indicated a weakness of liberalism and a kind of social democratic totalitarianism. To overcome such defects, 'civil society' (civilt samhälle) had to be created or revitalized. ${ }^{11}$

Swedes do tend to conflate 'state' with 'society'. They may demand that 'society' - rather than the private or voluntary sector - take responsibility for social services or, conversely, that 'society' should now leave many of its functions to the private and voluntary sectors. ${ }^{12}$ However, this kind of conceptual use is not uniquely Swedish. In fact, all Nordic political languages commonly conflate 'state' and 'society', though differences of degree may be seen in how frequently 'society' refers to the state or to the state and municipalities together. It is not difficult to find examples of such society-as-public-authorities uses of 'society' in all the languages. The Swedish critics were obviously wrong when they associated this conceptual historical phenomenon with a strong social democracy. There is much in common in the Swedish and 
Finnish ways of using this concept, yet in Finland, since the Civil War of 1918, social democracy has been much weaker than in Sweden. In fact, the conceptual confusion regretted by the critics had begun much earlier than the era of an expanding public sector and corporatism - i.e. those practices that the critics referred to as the major links between state and society and the reasons for the lost understanding of the boundaries between them. How should we then understand this conceptual confusion and its political implications?

One may argue that Nordic political languages conserved elements from the political philosophy existing before the nineteenth century, when civil society did not mean a sphere separate from the state but was a way of conceptualizing the state. ${ }^{13}$ The Nordic use of 'society' for the state implied that the state or public power was supposed to be capable of involving associative, integrative and inclusive principles of 'society' and 'the social'. However, the society-as-state usage also implies that society carries out the normative force of the state. In Finland, the conception of the state in terms of its societal, associational principles was seemingly subordinated to this latter aspect of society-as-state usage. The influential role of the Hegelian tradition in Finnish nation-building, represented especially by the 'national philosopher' Johan Vilhelm Snellman, contributed to such a view of the state. Later, a notion of politics as the non-political fulfilment of externally determined necessities was reinforced by experiences that were easy to interpret as issues of national existence. The experiences of World War II, especially the Winter War of 1939-40, came to have a long-term ideological legacy. During the Cold War, the national political agenda and national political agency were shaped by the necessity to cope with the tight limits placed on its room to manoeuvre in international politics. 
According to the social democratic ideology developed in the Nordic countries, the state could and should be changed into an instrument of political will and planning. However, this mode of thought never achieved a hegemonic position in Finland. One can argue that in Finland - in accordance with the Hegelian-Snellmanian legacy - a wide spectrum of political forces have viewed rational agency as an inherent property of the state itself, and politics has been supposed to put into action the agency of the state.

The ideal of national consensus did not imply an absence of conflicts. Finland has a more conflict-laden past than the other Nordic countries. The Civil War of 1918, with its class-based preconditions, had many long-term effects on social memory and political institutions. In the post-World War II era, the relatively strong support of the communists was one of the political phenomena that made Finland exceptional in the Nordic context. In industrial relations, obvious 'low-trust' elements appeared until the 1980s, indicated by comparative strike statistics. The parliamentary system was unstable, and short-lived governments were typical until the early 1980s. The Finland of too-much-conflict and the Finland of too-much-consensus were intertwined. Conflicts deepened as they easily turned into struggles over the right way to define and represent the general national interest and the right to talk in the name of the 'people' and 'society'. ${ }^{14}$

Just who represents the true interests of the whole was a core topic and question in the struggles between the Fennomanians and the Liberals after the mid nineteenth century. The former, inspired by a mixture of Herderian and Hegelian ideas, imagined the nation as a language-based cultural community and were active in attempting to substitute Finnish in place of Swedish as their own family language. The latter, in turn, were oriented towards developing the idea of a nation based on a constitution, including maintaining the continuity of Swedish as 
the language of education and cultural connections to Sweden. However, both parties associated the true interests of the whole with the concept of society, and neither of them seem to have adopted any clear distinction between the state and society in their argumentations. The Hegelian distinction between Staat as a sphere of freedom and bürgerliche Gesellschaft as a sphere of necessities was important for Snellman in his philosophical works but much less so for the Fennomanians following in his footsteps. The idea of civil society as a sphere of freedom outside the authority of the state, in turn, did not assume any major role in how the Liberals used the concept of society; they as well associated this concept with the entity of the nation. ${ }^{15}$

The concept of society was provided with a normative charge that implied both requirements and legitimations for the state. Paradoxically, 'state' and 'society' were in late nineteenth century Finland turned upside down with respect to the concepts of Hegel. Yhteiskunta or samhälle frequently referred to the state in contexts in which the state was seen as an agent with ethical capacities, while valtio or stat was often used for those legal coercive institutions that Hegel had included in bürgerliche Gesellschaft.

Yhteiskunta clearly carried out the normative force of the state in a series of articles, which placed 'the labour question' on the Finnish political agenda in 1874 . It was written by one of the foremost Fennomanian leaders, Yrjö Koskinen or Georg Zacharias Forsman, by his original Swedish name:

Yhteiskunta, i.e. the state [valtio], is the foundation for all historical progress. The mission of yhteiskunta is to watch over all the areas of common life [yhteiselämä], including the economic, to see that selfish interests and undertakings do not gain 
such free reign as would completely doom the lot of the weaker in that battle or as would lead yhteiskunta itself into ruin. ${ }^{16}$

Yhteiskunta (= the state) should regulate yhteiskunta (= societal practices) in order to bring resolution to the yhteiskunnallinen (= social) question. Koskinen's yhteiskunta was defined in a political context in which the Fennomanian movement had made 'the will of the people' a fundamental basis of their political argument and of the legitimation of power. ${ }^{17}$ At the same time, they viewed 'the people' and 'its will' as a problem needing oversight and definition. This yhteiskunta called for a moral relationship between the state and the people. Implicitly, there were two normative kinds of yhteiskunta: one referred to the state as carrying out the best interests - and, therefore, the will - of the people; the other referred to the population living within the order maintained by the state. As a normative concept, yhteiskunta offered a means for determining what actions represented the people's real and correct will and what actions constituted simple rebellion arising from the dangerous potentials of the social question.

The notion of society as carrying out the general interests of the people and of society as constituting the conditions for living within the state became entwined in a variety of ways. The conservative Fennomanian, Agathon Meurman, gave a defence at the Finnish National Economic Association in 1886 of yhteiskunta and its 'basic pillars: religion, family and property' against the misconception that ' $y$ hteiskunta was solely responsible for all the afflictions the individual suffers or thinks he suffers'. According to Meurman, 'the development of society' with all that such a development entails is moving towards making improvements to the position of labour and narrowing class differences. The causes of the ills and discontentments reside in human beings themselves. ${ }^{18}$ The dual nature of yhteiskunta was even more clearly fleshed out in the 
manifestos of the labour movement. The predominant conditions were referred to as 'class society' (luokkayhteiskunta) in the Finnish Social Democratic Party's (est. 1899) first explicitly socialist programme, the Forssa manifesto in 1903, which followed the Marxist model of the Austrian Social Democrats. After harshly critiquing society, the programme demanded that the means of production be taken into society's possession. ${ }^{19}$

Thus, one can distinguish between a normative and a descriptive society. The combination of these two societies can be characterized as a society capable of self-criticism. The concept of society referred to normative criteria and capacities, and these criteria and capacities were then applied to an empirical society in which need, poverty, class divisions, discontent and a lack of discipline were recognized. However, not only was society capable of self-criticism: it also possessed self-anticipating capacities. The concept of society became, in Koselleckian terms, a temporalized 'instrument for the direction of historical movement', as social problems and solutions were defined from a peripheral perspective.

\section{An Instrument for the Direction of Historical Movement}

The particular overlapping of temporal and spatial dimensions appears important in terms of how the modernizing nation-state society was adopted as the framework for defining social problems and solutions in the countries of Europe's northern periphery. The elite groups active in the nation-building processes consciously adopted the distinction between what later came to be referred to as centre and periphery. According to this view, the educated elite of a peripheral country, and later the popular movements, e.g. the labour movement, could and should define their political tasks on the basis of the knowledge of more developed - or more 'civilized' countries. Problems should be anticipated and solutions should be planned by acquiring 
information on the experiences, solutions and mistakes in what were seen as centres of industrial modernization. ${ }^{20}$

In a country like Finland, which was small and, even by Nordic standards, late to industrialize, international comparisons came to play a particularly prominent role. From the latter half of the nineteenth century onwards, such comparisons became integral to the way the educated elite analysed society and defined sociopolitical tasks. The outside world provided a framework of external preconditions and constraints, hopes and threats, as well as impulses, but also alarming ideas, models but also cautionary examples, points of reference but also boundaries to the possible.

A good example is the aforementioned series of articles by Yrjö Koskinen in 1874 on 'the labour question'. He argued that efforts should be made to forestall threats to social stability by examining Finnish conditions 'from a European perspective', by trying to learn, in other words, from what was happening in countries that were more highly developed than Finland.

Koskinen's articles also demonstrated that both the threat - that is, socialism - and the economic system, which provided a breeding ground for socialism through its inherent conflicts between capital and labour, were perceived as international phenomena. It was considered important to learn from both the solutions and the mistakes of these countries so as to be able to exploit what Alexander Gerschenkron has called 'the advantages of backwardness'. ${ }^{21}$

Many ideas and impulses were transferred to Finland via Sweden, but it was only after the 1930s and, especially, after World War II that Sweden itself was looked at as representing the forefront of modernization. Nevertheless, contacts with Sweden and the positioning of Finland in Norden came to play an important role for the 'comparative imagination' that was constitutive of the nation as an 'imagined community'. ${ }^{22}$ Promoted by intra-Nordic communication in different 
fields of social knowledge since the late nineteenth century, the word 'Nordic' came to represent an active future-oriented peripheral perspective towards the centres of modernity that varied according to the topic.

In general, the Nordic countries developed into small, relatively open, economies that were each country in its own specific way - highly dependent on exports and exposed to the cycles and crises of the world economy. This international dependence provided the preconditions for the articulation of strong notions of national economy and national society and for the legitimacy of the active role of the state, often expressed in the form of 'society'. ${ }^{23}$

Society was at the same time both an agent and a target of knowledge and politics. In this dual understanding of the concept of society, the former aspect referred to the state, while the latter aspect, in turn, was associated with the conceptual construction called 'economy'. This implied society's dynamics of wealth creation and integration but also the potential for destruction and disintegration. In relation to economy, the agency of society as the state also had two sides. When the state was called 'society', it referred, on the one hand, to the interests of the national economy above private economic interests and, on the other hand, to the social principle that put limits on the economic actions aiming to preserve or reconstruct social cohesion. Transfers and translations of ideas from 'more civilized countries', motivated by the effort of anticipating problems and solutions, were in Finland a crucial practice in the development of this dualism that later became a core part of the concept of welfare state. One precondition of such a conceptualization was that the nineteenth-century uses of 'welfare' were first pushed aside by a vocabulary built around the concept of society. 


\section{Substituting Social for Welfare}

In the German sciences of government, Polizeiwissenschaften, which were developed on the basis of the tradition of cameralism, combining Wohlfahrt and Polizei was a way of conceptualizing the relationship between the state and economy. ${ }^{24}$ The Polizei functions of the state, Wohlfahrtspolizei (welfare police) and Sicherheitspolizei (security police), were supposed to guarantee the general welfare and order of the population. In Finland, Johan Ph. Palmén, professor of law at the University of Helsinki, was inspired by the work of Robert von Mohl, who aimed to subordinate both Wohlfahrtspolizei and Sicherheitspolizei under the constitutional principles of Rechtsstaat. In his juridical handbook published in 1859, Palmén used the term välfärdspoliti, the direct Swedish translation of Wohlfahrtspolizei. ${ }^{25}$

The first time the compound word välfärdsstat appeared in newspapers or journals in Finland seems to have been in 1878. In a magazine put out by the student nation of Nyland province at the University of Helsinki, Album utgifvet af nyländningar, C.F. Vendell critically assessed 'the attacks of the Social Democratic School against the property' and in this context also discussed the views of German Socialists of the Chair (Kathedersozialisten). In their view, Vendell wrote, the state was 'not only a state of law but also a welfare state' (icke allenast en rätts- utan äfven en välfärdsstat). The Socialists of the Chair believed that viewing the state as a welfare state would promote the interests of 'the fourth estate' (workers) in a way corresponding to how it earlier as a state of law had elevated those of the third estate. Vendell, a liberal student, was not convinced, noting that the rise of the third estate had only indirectly been an outcome of legislation. ${ }^{26}$

One may find in Vendell's text a remarkably early appearance of a concept that only much later gained frequent use. On the other hand, however, it is reasonable to assume that here - in 
Vendell's article as well as in the vocabulary of the Socialists of the Chair - old cameralistic tools were applied in a new context. It was a context in which society was discussed as processes and structures that could not be derived from the Polizei functions of the state but instead resulted from the unintended consequences of its members' actions. The new 'labour question' and 'social question' were constructed in this context, and the cameralistic vocabulary lost much of its applicability. Combining welfare with state, politics or policies did not, however, become an influential way of conceptualizing the contents of and solutions for the 'labour question' and 'social question'.

As a translation of Wohlfahrt, välfärd was also later occasionally used as an attribute of the state. The political situation in France was the topic of an article taken from the Austrian newspaper Neue Freie Presse and published in Swedish by Nya Pressen in 1899. According to the article, though socialists were different in Germany and France, both ultimately believed in the coming of the great day when they would take control of political power and create den sociala välfärdsstaten (the social welfare state). ${ }^{27}$ Later, in 1901, välfärdspolitik (welfare policy) was used as a characterization of political objectives when discussing French politics. ${ }^{28}$ Välfärdspoliti disappeared with cameralism, but välfärdspolisen (welfare police) appeared in 1907 in news about Russian police reforms. ${ }^{29}$

Both the Swedish välfärd and the Finnish hyvinvointi appeared in newspapers, journals and other publications in Finland in the nineteenth century. These words could in part be used synonymously, yet the contexts of their usages differed significantly. Hyvinvointi was a word used to describe positive conditions in the life of an individual, a family, a community or a nation, but it did not refer to any action or actorness, and it was not used in compound words as an attribute of any particular activities or institutions. In this respect, it was closer to välstånd 
(wellbeing) than välfärd in Swedish.

Välfärd was used in compound words and associated with actorness. However, since the late nineteenth century the most common context in which välfärd was combined with agency and institutions was not in respect to governmental policies but, rather, regarding the employer activities of industrial companies. The Swedish vocabulary for the paternalist policies of industrial companies - in Finland as well as in Sweden - made use of välfärd. The terms commonly used for these employer practices, including, for example, housing arrangements, were välfärdsinrättningar or välfärdsanstalter (welfare institutions).

In these contexts, hyvinvointi was not used as a Finnish translation of välfärd. In the Finnish version of Palmén's juridical handbook, Elias Lönnrot, best known for compiling the national epic Kalevala, translated välfärdspoliti as onnivallinto (the state of happiness). ${ }^{30} \mathrm{~A}$ corresponding translation was made in a newspaper report on a meeting of the Finnish Technical Association (Tekniska föreningen i Finland) in 1883, in which a lecture was given about välfärdsinrättningar (welfare institutions) in the Krupp factory in Essen. The Finnish translation was onnilaitokset (institutions of happiness).${ }^{31}$ However, this translation was not elevated to an established position. In the late nineteenth century and during the first decades of the twentieth century, the most popular Finnish translation of companies' välfärdsinrättningar was työväenmenestyslaitokset (institutions for workers' success). In the 1920s and 1930s, the most common expression was työväenhuolto (workers' service). Then, during World War II the adjective 'social' was adopted as the attribute best describing such employer activities, työnantajien sosiaalinen toiminta (employers' social action), in order to remove the patronizing vocabulary and increase the legitimacy of these practices as a tool for creating indu strial peace. ${ }^{32}$ The steps taken leading from 'welfare' (välfärd in Swedish, and onni or menestys but not 
hyvinvointi in Finnish) to 'social' as the idea best describing the attributes of employer policies had their preconditions in how the vocabulary used to discuss the concept of society, including the associating adjectives, changed over the years. Consequently, space then opened up for again combining welfare with the state, yet in a different way to how it had been done via the traditions of cameralism and Polizeiwissenschaften. However, this change only occurred after the agency of the state and the targets of state action had been conceptualized via the concept of society, and the attributes of policies had been derived from this concept.

\section{National Economy and Social Order}

In late nineteenth-century Finland, the concept of society and associated adjectives used as attributes of policies played an effective role and were in varying ways related to the concept of economy. Society and economy were combined in the words samhällsekonomi and yhteiskuntatalous. These were used synonymously with nationalekonomi and kansantalous (national economy). The Fennomanian association Kansantaloudellinen yhdistys (The Finnish National Economic Association), founded in 1884, was a central forum for examining the social question in its rural and urban forms, and inspiration came from the German historical school of economics and Verein fûr Socialpolitik. The Swedish-language counterpart, Ekonomiska Samfundet i Finland (The Finnish Economic Association, est. 1894), was for its part oriented towards liberalism and the mechanisms by which the market economy functioned. ${ }^{33}$ Since the turn of the century, the two aspects of relating society to economy - the general economic interest above private interests, or national economy (samhällsekonomi, yhteiskuntatalous), and the social principle putting limits on economic action, or social policies (socialpolitik, 
yhteiskuntapolitiikka/sosiaalipolitiikka) - gradually became more distinct, also in terms of academic studies.

However, even after this distinction the quest for nationalistic purity when refining Finnish political language - that is, the vigorous search for vernacular ingredients - contributed to the normative charge of the concept of society. 'Social' had been translated in Finnish using an adjective directly derived from the Finnish word for society, yhteiskunta, namely yhteiskunnallinen. In his writings about the labour question in 1874, Koskinen distinguished between two opposing views, 'economism' and 'socialism', both of which he criticized. The 'economism' viewpoint, based on truths conceived by Adam Smith, 'contained only the natural side, but left completely out of the equation the ethical dimension, that is, yhteiskunta'. The other view, which "has trumpeted itself as yhteiskunnallinen and thus taken the name of "socialism", had understood sociality (yhteiskunnallisuus) in a dangerously misguided way according to Koskinen. $^{34}$

Since valtio (state) and yhteiskunta (society) were often used synonymously and 'social' had been translated as yhteiskunnallinen, options were open for portraying political battles as being confrontations between 'pro-society' and 'anti-society' forces. These options were used, not least, in the conclusions drawn from the Civil War of 1918. For the victorious White side, the image of society as an acting subject was reinforced: 'society' had to robustly defend itself against 'anti-societal' ideologies and actions. ${ }^{35}$ The wide semantic range of yhteiskunnallinen made it linguistically possible to lump many kinds of people together into the same 'anti-society' category. The concept could cover anyone from 'social misfits' with diagnosed antisocial disorders to individuals guilty of subversion or state treason. The noun form of the word, yhteiskunnanvastaisuus (societal contrariness, societal opposition), could lend itself also to racial 
hygiene propaganda about the threat of 'degeneracy'. It was used in just such a way by rightwing debaters when attempting to account for the Red rebellion against the state in the Civil War and in the directions given to guide the creation of 'a new Finland' ${ }^{36}$

In the first decades of the twentieth century, the state's regulative activities concerning 'the yhteiskunnallinen question' were still most often called yhteiskuntapolitiikka, a translation of German Sozialpolitik and Swedish socialpolitik. ${ }^{37}$ When using the word in this compound form, yhteiskunta referred to the specific target of politiikka (policy), mainly class relations and the position of the working class. However, yhteiskunta also brought other connotations to the word: yhteiskunta (i.e. the state) was the party that determined and executed these policies, and these policies in turn promoted and strengthened yhteiskunta (i.e. the prevailing state-maintained social order within the nation state).

However, yhteiskunnallinen - or the prefix yhteiskunta- in compound words - was not an unproblematic translation of 'social'. Obvious difficulties were linked to the distinction between 'social' and 'political'. The vernacular construction of the adjectives for 'social' and 'political' was based on the distinction between society and state, yhteiskunta and valtio: 'social' was yhteiskunnallinen and 'political' was valtiollinen. At the same time, yhteiskunta was frequently used synonymously with valtio. ${ }^{38}$

Translating 'social' as yhteiskunnallinen had in some cases proven difficult even before the 1920s. When the Finnish Labour Party approved its socialist programme in 1903, it changed its name to the 'Social Democratic Party of Finland', emphasizing social democracy as well as internationalism. From 1917 to 1919, several agencies were formed using sosia(a)li- as a prefix, including sosialitoimituskunta/sosialiministeriö (Ministry of Social Affairs) and sosialihallitus (National Board of Social Affairs). In some cases, the Finnish expression for the Swedish word 
social was neither sosiaalinen nor yhteiskunnallinen. In the Parliament, which had since 1906 been based on general suffrage and a unicameral organization, the permanent committee preparing social-political issues was called in Swedish socialutskottet, but in Finnish it was työväenasiainvaliokunta (committee for labour issues). This dualism remained until the 1960s. Nevertheless, the synonymity of sosiaalinen and yhteiskunnallinen does not seem to have been an issue yet in the 1920s. Some wrote of 'the sosiaalinen question', despite the foreignness of the word. The Swedish-speaking theologian G.G. Rosenqvist did so in his book on this topic, published in 1923 in both Swedish and Finnish, Sociala frågan och socialismen, Sosiaalinen kysymys ja sosialismi (The Social Question and Socialism). However, yhteiskunnallinen was still the favoured term, as when, e.g. the University of Helsinki student journal referred to the Settlement League's educational activities in working-class areas as yhteiskunnallinen work. ${ }^{39}$ Signs were emerging in the 1920s and 30s that the Finnish political language was neglecting precisely what was in need of conceptualization. Some were seeking 'political' (poliittinen) concepts and options, which would not simply refer to the state (as in valtiollinen), and 'social' (sosiaalinen) concepts and options, which would not simply refer to society (as in yhteiskunnallinen). As a result of this trajectory, the meanings of the existing terms valtiollinen and yhteiskunnallinen changed as well. Related to the changes was also the fact that yhteiskunta was becoming less and less applicable to communities smaller than that of the nation state. ${ }^{40}$ Using the concept of society synonymously with the concept of state was made easier by moving to a less vernacular-fixed vocabulary. 


\section{Societal and Social Policies}

The earliest explicit distinction between yhteiskunnallinen (societal) and sosiaalinen (social) may have been drawn by Eino Kuusi, a founding father of the discipline called 'social policy' in Finland, in his two-volume textbook Sosialipolitiikka (Social Policy), published in 1931. It was no longer any great novelty that Kuusi did not use the term työväensuojelu (labour protection) in its earlier, broader meaning, which had, until the 1920s, often included not only the risks in working life but the whole range of social-political agendas. What was a novelty was that he also rejected the previously popular yhteiskuntapolitiikka and chose to refer only to sosialipolitiikka from the title onwards. He argued his decision on the grounds that the words produced different effects on the imagination. In his judgement, the word sosialinen:

... is connected to the feeling of commonality, or mutual aid, which is present in socius (which is toveri (companion, comrade)). Since yhteiskunnallinen also lacks this warmth, yhteiskuntapolitiikka does not quite match the concept. Since we lack any other Finnish alternative, I consider 'sosialinen' and 'sosialipolitiikka' to be the best choices, as they are also quite well suited to Finnish. The only caveat is to be careful against confusing these words and their meanings with what is meant by 'sosialistinen' (socialist as adjective) and 'sosialismi', which means something altogether different. ${ }^{41}$

However, Eino Kuusi did not by any means abandon yhteiskunta. The motives of social policy in his presentation took into full account the interests, needs, demands and obligations of yhteiskunta. In his argumentation, sosialinen was associated not only with warmth and 
interactions between people but also with class conflicts, which were a threat to social cohesion and to society itself. Kuusi can be interpreted as wishing to reserve the use of yhteiskunta and yhteiskunnallinen to refer to an essentialist national cohesion, one which had been endangered by the revolution attempted in Finland in 1918.

At the same time, a distinction between social and societal also emerged from another perspective. It stemmed from the dualism in how society was related to economy. In the 1930s, new meanings were attached to the distinction between a society associated with national economic interests and a society associated with social cohesion. This conceptual change was supported by the lessons drawn from the experiences of the Great Depression, and it appears that it was inspired by ideological developments in other Nordic countries.

As an attribute of economic life, the adjective directly derived from the word for 'society' - in Finnish yhteiskunnallinen, in Swedish samhällelig, in Norwegian and Danish samfundsmessig was increasingly associated with the principles of a 'planned economy', which, during the economic depression of the 1930s, became a popular objective at the international level, albeit with various political colours. According to this line of thought, 'society' would actively steer and rationalize the economy, and such steering was 'societal'. ${ }^{42}$ Following the example of Scandinavian social democratic parties, Eero A. Wuori's draft of the Finnish Social Democratic Party's economic policy programme 1933 spoke of how 'the anarchical system of capitalistic production' could be transformed 'into a plan-based, socialistic system of production under the power and leadership of society'. ${ }^{43}$ In the 1940s, during and after World War II, the adjective yhteiskunnallinen was in many texts still more explicitly associated with regulation and governance in the name of real economic rationality and rationalization. ${ }^{44}$ 
Sosiaalinen, in turn, had a quite different meaning in the context of economic rationalization. It was associated with the delimiting or compensating of those outcomes of economic development that endangered the welfare of those involved (notably the workers) and threatened the cohesion of society. As these concepts became associated with the distinction between public institutions and private life, they also became gendered so that yhteiskunnallinen (societal) came to have a masculine connotation and sosiaalinen (social), in turn, a feminine one. The strong links between the concepts of state and society contributed to the masculine connotations of 'societal' that carried over into public power and the domain of public life. As for 'social', its meaning was limited to what was between society and the family, or between the public and private domains, and was thereby marked as feminine. In the 1940s, sosiaalinen and social were also adopted in the field of industrial welfare. In large industrial companies, these activities greatly expanded in Finland soon after World War II, carried out predominantly by female 'social workers', often under the direction of male 'social directors' ${ }^{45}$

In the 1950s, the yhteiskuntapolitiikka that Eino Kuusi had abandoned in 1931 returned in a new way. In his university textbook Sosiaalipolitiikka (Social Policy), Armas Nieminen defined the hierarchy between the two. Yhteiskuntapolitiikka was the general concept for 'efforts and measures to organise society so that the conditions of society are regarded as efficiently suited and right for the purposes'. Sosiaalipolitiikka was a sub-concept for 'measures intended to ensure a level considered fair in the standard of living, social security and amenities for society's various groups, families and individuals'. Sosiaalipolitiikka was thus no longer based on a concept of 'class' and class conflicts. Nieminen portrayed the actors and interests behind sosiaalipolitiikka in stating that this kind of policy was 'on the one hand, a practical expression of the common responsibility felt by society for its various groups and citizens; on the other 
hand, it involves different groups' own activities aimed at promoting and realising their own self-interests'. He related this tension to another contradiction that drives social policy: planning based on the knowledge of experts and involving compromises between differing goals and interests. ${ }^{46}$ The inference is that, for Nieminen, yhteiskunta was a social actor functioning as the centre of social solidarity and with the ability to set up projects and goals based on a scientific knowledge of itself.

In 1961, Pekka Kuusi, Eino Kuusi's nephew, published a book on social policy of the 1960s, 60-luvun sosiaalipolitiikka (Social Policy for the 60s) The book was initiated by The Social Policy Association in Finland, and it was later translated into Swedish and English. The book is often regarded as laying out the plan for the Finnish welfare state, but in fact Kuusi did not use the concept of welfare state. Instead, he further developed the hierarchical order between yhteiskuntapolitiikka and sosiaalipolitiikka. His perspective differed from Nieminen's in that he programmatically treated sosiaalipolitiikka as a component of yhteiskuntapolitiikka and called for the actors of the former to be clear about the general goals of the latter. Pekka Kuusi did not find any essential contradiction between the universal interests of society and the particular interests of various groups, as had Nieminen. Instead, inspired by Gunnar Myrdal's theory of circular cumulative causation, Kuusi expressed his strong confidence in virtuous circles within modern society: 'Democracy, social equalization and economic growth seem to be fortunately interrelated in modern society. Social policy seems to spring from free and growth-oriented human nature. ${ }^{47}$ Social policy played an important role within this fortunately interconnected society. In such a 'growth-oriented society', 'social' was no longer a counter-principle to 'economic', and the society, 'our society', was simultaneously the subject, object and framework of all growth-oriented action. 
Finnish social policy language developed counter to its mainstream uses by the postwar social sciences, which were in Finland greatly influenced by American sociology. The distinction between yhteiskunnallinen and sosiaalinen paralleled the German distinction between gesellschaftlich and sozial, but it was difficult to find support from the English language for this kind of distinction. In any case, in social policy texts the conceptual linkage of social policies with the state was in the 1950s and 60s elaborated through the distinction between societal and social rather than by means of the concept of welfare state.

\section{Welfare}

Hyvinvointi was the Finnish word for welfare and could be used synonymously with the Swedish word välfärd. However, as noted above, in the late nineteenth and early twentieth century there were contexts in which hyvinvointi did not work as a translation of välfärd. It was not applicable as an attribute of governmental, voluntary or private activities or actors. It was not used in compound words. In such connections - for example in the translations välfärdspoliti (welfare polity) for government-related actions and välfärdsanstalter (welfare institutions) for employerrelated actions - the words onni (happiness) and menestys (success) appeared as Finnish equivalents to welfare, välfärd and Wohlfahrt, instead of hyvinvointi.

However, when the concept of welfare state was introduced in the Finnish vocabulary in the early 1950s, it was not constructed by means of the words for 'happiness' or 'success' but by extending the usage of hyvinvointi. This linguistic operation had implications with respect to the references, contexts of use and valuations of the concept of welfare state in Finland. On the one hand, the neologism hyvinvointivaltio did not imply any older cameralistic or paternalistic connotations that might have been included in the words Wohlfahrtstaat and välfärdsstat or 
'welfare state' as such. On the other hand, hyvinvointivaltio was, and is, easy to use as a description of socio-economic circumstances rather than as the agency of the state. The Finnish conceptualization of it seems to have shaped the Swedish political language in Finland. Välfärd never gained such an active role as an integrating attribute of policies as it did in Sweden. The party focusing on the representation of Swedish-speaking Finns, the Swedish People's Party, added this word to its party programme for the first time in 1964 (välfärdsutvecklingen, 'welfare development'). ${ }^{48}$

The concept of welfare state was introduced in the Finnish vocabulary in the early 1950s, but in the following decades it very seldom appeared in programmatic texts where governments and parties described their policies. In the policy programmes of the Finnish parties, hyvinvointivaltio has occasionally appeared since 1954, but it was no earlier than 2003 that the word was for the first time specifically included in a government programme. When specifying and interpreting these findings, it is useful to first focus on the usages of the word 'welfare' in such programmatic documents. It appears that, in the defining of political objectives, välfärd or hyvinvointi were not used as central concepts before the end of the twentieth century.

In the period from the foundation of the republican political system in 1919 until World War II, the political programmes of new governments were introduced in speeches that the prime ministers gave at the beginning of their governments. After World War II, the practice of adopting particular government programmes was established. Only since 2003, however, has an official Swedish version of the whole programme also been published. The length of these programmes greatly increased after the 1980s, as coalition-based majority governments, sitting the whole four-year period between parliamentary elections, became the rule. Before the 1980s, 
short-term governments, including both majority and minority cabinets, were characteristic of the Finnish political system.

Between the end of the Civil War, May 1918, and the end of the Continuation War, September 1944, Finland had twenty-seven governments. Only two of them used the word 'welfare' (hyvinvointi) in their programme manifestos. In 1919, Prime Minister Kaarlo Castrén noted in the programme speech of his bourgeois centre-party government that the finances of the state and 'the welfare of the people' (kansan hyvinvointi) should be based on 'the healthy development of agriculture, manufacturing, trade, shipping and other industries' ${ }^{49}$ The second time 'welfare' appeared was in a speech that Väinö Tanner gave in Parliament in 1926, manifesting the programme of his Social Democratic minority government, which, formed less than ten years after the Civil War and the White victory, was a remarkable phenomenon. In Tanner's speech, the concept of welfare appeared in a way quite similar to how Castrén had used it - that is, as a word for economic prosperity. Tanner told Parliament that the government was well aware that 'a necessary precondition of the country's political (valtiollinen) success was its economic progress and welfare' and would therefore pay special attention to 'the further development of the country's economic forces'. ${ }^{50}$ In both cases, 'welfare' appeared as an outcome of successful economic action that could be supported by correct economic policies. It was not associated with a redistributive role of the state or with any other policy areas other than the economic one.

When analysing Finnish conceptualizations in the Nordic context, the vocabulary used by the social democratic parties deserves special attention. Nordic cooperation between social democratic parties and trade unions was reinforced in the 1930s, and it played a significant role as a source of inspiration for the Finnish Social Democrats. In their campaign before the 
parliamentary elections of 1936, the Finnish Social Democratic Party had 'welfare' as one of its main slogans: Hyvinvointia kaikille/Välstånd åt alla (Welfare for all). ${ }^{51}$

\section{<Insert Figures 5.1 and 5.2 next to each other>}

Figures 5.1 and 5.2 'Welfare for all', a Social Democratic election poster, 1936, in Finnish and Swedish. Reprinted with permission by The Labour Archive in Finland.

The slogan indicates the influence of the Nordic social democratic community, in which 'welfare' had strongly emerged as an objective. However, the way the Finnish Social Democrats used this word differed importantly from how their closest Nordic comrades, the Swedish Social Democrats, politicized it. While the Swedish Social Democrats adopted 'welfare politics' (välfärdspolitik) as the overarching concept for integrating their reform policies, the Finnish variant, 'welfare for all', referred to outcomes of good policies, the wellbeing of people, rather than to the characteristics of those policies themselves, or to the politics of policies. ${ }^{52}$ In the Swedish translation, using välstånd instead of välfärd, the difference from Sweden was even more evident.

The Social Democratic Party's slogan during the 1936 electoral campaign did not lead to any breakthrough with respect to 'welfare'. In 1937, the Social Democratic Party and the Agrarian Party, together with social liberal forces from the smaller National Progressive Party and Swedish People's Party, formed a joint government inspired by the Scandinavian coalitions of 'workers and farmers'. The programme speech given by Prime Minister A.K. Cajander of the National Progressive Party did not include the word 'welfare', not even in the economic sense in which Tanner had used it in $1926 .{ }^{53}$ In the Social Democratic Party's manifesto before the 1939 
parliamentary election, the expressions 'general welfare', 'the welfare of the whole people' and 'the welfare of the countryside's less advantaged people' appeared, yet 'welfare' did not play any integrative role in the manifesto. ${ }^{54}$

'Welfare for all' implied the idea of redistribution, yet after the late 1930s 'welfare' was still mostly a concept used to describe the outcomes of economic success. After Tanner, it took almost twenty years before the government next added the word 'welfare' to its programme manifesto. It was a left-majority government of the Agrarian Party, the Social Democratic Party and the Finnish People's Democratic League. The last-mentioned organization had been formed by the communists and left-wing social democrats in 1944, after the end of the Continuation War and the emergence of Finnish communism from illegality to legal party status. In the agreement included in the programme manifesto of the new government in 1945, these three equally large parties - the largest parties in Parliament - declared that their coalition aimed to conduct an effectively planned economic policy that would raise 'the general standard of living and welfare'. ${ }^{55}$

After two governments in the years 1945-48, there have been in Finland two 'popular front' governments in which the Social Democratic Party and the Communist Party formed the majority, both during the very rare period of socialist majority in Parliament in the years 196670. In addition, the Social Democratic Party twice formed a minority government after World War II: once in the period 1948-50 and again in 1972. The word 'welfare' appeared in the programme of one of these four left-wing governments. The programme of Mauno Koivisto's government in 1968-70 stated that "private entrepreneurship aimed at the welfare of our society and people should be effectively supported' ${ }^{56}$ 
True, in a few other government programmes of the 1950s and 60s, 'welfare' had been associated not merely with the outcomes of successful economic action but also with a redistributive agency of the state. The programme of Ralf Törngren's government in 1954, a coalition of the Social Democratic Party and the Agrarian Party, aimed to increase 'the welfare and social security of our people' and mentioned social insurance as a means for doing so. According to the programme of the Agrarian Party minority government in 1957, led by V.J. Sukselainen, 'the economic and social welfare of our people' was the main objective. The association of welfare with redistributive policies was more pronounced in the programme of Ahti Karjalainen's government in 1962-63, which had the Agrarian Party as its dominant force but was completed with trade union leaders from the minority faction of the recently divided Social Democratic Party. The government especially wanted to ensure that 'the wage earners and small-scale farmers who were in a weaker position would feel their life secured and increasingly get their share of the growth of our country's economic, social and educational welfare'. ${ }^{57}$

It was much later that 'welfare' was used in government programmes as part of compound words referring to 'state', 'society' or 'policy'. However, such usages had occasionally appeared since the early 1950 s in public debates and party programmes.

\section{Welfare State and its Right-wing Critics}

Hyvinvointivaltio seems to have been occasionally used in the first years of the 1950s in translations of foreign news. ${ }^{58}$ However, it was only in 1954 that it was included in the annual list of new words of the year, published by the popular Finnish 'citizen's yearbook', Mitä, Missä, Milloin (What, Where, When). One of the first to introduce the word hyvinvointivaltio was the young social liberal lawyer Kauko Sipponen, who was impressed by Fabian ideas and British 
postwar development. In a book published in 1954, in which representatives of different fields of societal life, concealed by pseudonyms, discussed topical national problems, Sipponen defined the welfare state in the context of an East-West confrontation. He had noticed a new way of understanding the role of the state in some Western countries, notably Britain and the Nordic countries, which combined the goal of full employment with the principle of individual freedom. This understanding of the state had resulted in what Sipponen wished to call hyvinvointivaltio (welfare state) or yhteishyvävaltio (common good state).${ }^{59}$ The latter conceptual innovation did not enjoy any immediate success ${ }^{60}$ though hyvinvointivaltio was gradually, but not always eagerly, adopted in wider use.

The first political party programme to use the word hyvinvointivaltio was the Social Democratic Party's programme for economic policy in 1954, according to which 'the system of social security' was 'a basic feature of the welfare state'. The programme was published for the electoral campaign of 1954, and individual Social Democratic candidates advocated hyvinvointivaltio in their election posters, associating it with full employment and social security. ${ }^{61}$ However, the word did not gain any central role in Social Democratic rhetoric. In the party congress of 1955 , the British president of the Socialist International, Morgan Phillips, was the only one to mention 'welfare state', ${ }^{62}$ and the frequency with which the word was used barely increased in the party congresses of the next couple of decades.

To the extent that the word 'welfare state' was included in Social Democratic rhetoric, it was a way to manifest a Western and Nordic political orientation. In the electoral campaign of 1962, the Social Democratic Party published a full page advertisement in the largest newspaper, Helsingin Sanomat, assuring readers that 'the welfare state (hyvinvointivaltio) is a good thing, it is social democracy'. All countries where the Social Democrats were in charge of development 
rapidly advanced and built up the welfare state, 'with our Western neighbouring countries as examples'.63

The formulation indicated that not everyone found the welfare state to be 'a good thing'. The concept had also been used as a tool of right-wing critiques of public policies. In 1959, in its programme for municipal policy, the conservative National Coalition Party opposed the current 'efforts of the state to be a "welfare state"'. In its view, left-wing social policy was subordinating the individual to 'a subservient inmate of a "welfare state" led by a small group of politicians'. Defending the ancient tradition of 'Nordic democracy' was a major message of the programme, and the welfare state appeared as a left-wing threat against this tradition.

The National Coalition Party had in 1957 adopted the German Christian Democratic Party's slogan of 'social market economy' in its general party programme. ${ }^{64}$ Thus, one can conclude that the National Coalition Party found not only the welfare state and Nordic democracy but also the welfare state and social market economy as incompatible ideas. In the 1950s, the party also adopted the notion of 'people's capitalism', thus responding to socialist demands and redefining 'economic democracy'. In a programmatic text from 1966, 'people's capitalism' appeared not only as the concept for the proper meaning of economic democracy but also as the right way to construct a 'welfare system'. Through owner-occupied housing and by owning a car, television, refrigerator, washing machine, sewing machine and telephone as well as the tools of one's trade, more and more homes would have a share in 'the welfare system based on people's capitalism' (kansankapitalistinen hyvinvointijärjestelmä). Obviously, this system was supposed to be essentially different from the welfare state, although this concept was not mentioned in the programme. ${ }^{65}$ True, in the 1960 s changes appeared in how the party criticized the welfare state. For representatives of the younger generation, the major concern was excessive confidence in the 
possibilities of the welfare state to improve people's living conditions, rather than its fatal societal consequences, as described, for example, in the municipal programme of $1959 .{ }^{66}$

The Finnish conservatives - that is, the National Coalition Party - found the Social Democrats as their partners in the struggle against communism, and while they contrasted their policies with social democratic social policy ideas, they did so less sharply than did the conservatives in Sweden ${ }^{67}$ However, the anti-communist compliance with social-political reforms was not expressed by means of the concept of welfare state.

In Finland, as in other Nordic countries, the concept of welfare state was in the 1950s also utilized by Churchmen in their critique of governmental interference in the spheres of life in which confidence in God's will, an individual sense of duty and responsibility, respect for home and family and love for one's neighbour should prevail. Bishop Eino Sormunen published in 1958 a book entitled Hyvinvointivaltio ja henkinen elämä (The Welfare State and Spiritual Life), in which he argued that it was the task of the Church to prevent the state from developing into 'a total custodial state' (totaalinen huoltovaltio) and, by the same token, to strengthen 'the foundations of the state of law' (oikeusvaltio). Nevertheless, Sormunen did not share the demonizing critique the Norwegian bishop Eivind Berggrav had a few years earlier targeted against the welfare state, but called for more dialogue and cooperation between the state and the Church. ${ }^{68}$

In his work on 'social policy for the 60s' (1961), Pekka Kuusi did not use the concept of welfare state. For him, hyvinvointivaltio brought to mind a cowhouse-like image of well-fed people, which he did not want to associate with his message, as he later explained. ${ }^{69}$ However, the concept did appear in a critique of the book. The philosopher Urpo Harva, a leading figure in 
Finnish adult education, argued that the welfare state advocated by Kuusi would weaken an individual's possibilities to develop his or her human personality. ${ }^{70}$

Indeed, hyvinvointivaltio, to the extent that it was used as a concept describing the role of the state, was until the 1970 s most frequently used by right-wing and left-wing critics. As a tool of critique, 'welfare state' was often provided with an ironic charge. A popular encyclopaedia called Facta, published in eleven volumes in the years 1969-1974, included a short entry on hyvinvointivaltio. It stated that hyvinvointivaltio referred to the high standard of living and comprehensive social services typical of modern industrialized countries. The concept was often used 'in an ironic sense', however, meaning 'the detailed regulation of all areas by the state power and the restrictions of individual freedom'. The author of the entry seems to have agreed with this critique, as he continued in his characterization of the welfare state by saying the following: 'In addition, typical defects of the welfare state include that initiative becomes irrelevant, problems concerning the use of leisure increase, and obesity, together with subsequent degenerative diseases, becomes common. ${ }^{, 71}$

\section{Welfare State and its Left-wing Critics}

After the 1954 Social Democratic Party's programme for economic policy, it took more than ten years before the welfare state was next mentioned as a positive policy objective in a party programme. The Finnish People's Democratic League declared in 1967 that its goal was 'a highlevel independent and democratic welfare and culture state' (korkean tason itsenäinen ja demokraattinen hyvinvointi- ja kulttuurivaltio/en självständig och demokratisk välfärds- och kulturstat på hög nivå). The programme was based on the idea of extending democracy as the core of political and social reform, and the welfare state, imbued with the attributes 'high-level', 
'independent' and 'democratic', appeared as the result of a process of democratization that included, not least, 'economic democracy'. ${ }^{72}$

One may interpret the 1967 programme of the Finnish People's Democratic League as an attempt to redefine 'welfare state' by locating the concept within the context of democratization. The League, which included the Communist Party as its major force, had since 1966 - for the first time after 1948 - begun participating in a government coalition together with the Social Democrats and the Centre Party (the former Agrarian Party). In such a situation, incentives emerged for the parties to elaborate a political profile that demonstrated their crucial role as advocates of democratization. On the other hand, the programmes of the League had from the first beginning, since 1944, highlighted 'democracy' instead of 'socialism'. The Finnish People's Democratic League had aimed to become a wide alliance of different 'democratic forces', among whom the Communist Party was supposed to represent the working class and define its socialist mission.

The League's 1967 programme was published in the year of the $50^{\text {th }}$ anniversary of Finland's independence. The concept of welfare state had gained some popularity in historical accounts of the nation's successful development. Jouko Siipi, an assuredly non-socialist researcher of social policy, published a book on Finland's road 'from poverty to a welfare state'. ${ }^{73}$

\section{<Insert figure 5.3 here>}

Figure 5.3 'From poverty to a welfare state'. In Jouko Siipi’s book from 1967, hyvinvointivaltio primarily referred to improved living conditions and changes in social and occupational structures. Reprinted with permission by Tammi Publishers. 
In such accounts, hyvinvointivaltio referred to social and economic circumstances rather than to the functions of the state, thus actualizing 'wellbeing' as one meaning of hyvinvointi. In its programme of 1967, the Finnish People's Democratic League also used 'welfare state' in a similar manner - that is, as a description of social circumstances within a nation state, yet one that pointed towards a brighter future. At the same time, the combination of the attributes 'democratic' and 'independent' was obviously targeted against those who found the League and its communists a threat to the existing democracy and independence of Finland.

In the Finnish Social Democratic Party, a split had taken place in the late 1950s, and it prevailed until the end of 1960s. The new party, the Social Democratic League of Workers and Small-Scale Farmers, had its background in social democratic trade unionism, but it did not receive much electoral support. In 1967, the party adopted a radical leftist programme, and it was here that the concept 'welfare policy' or 'welfare politics' (hyvinvointipolitiikka) for the first time appeared in a Finnish party programme. The programme contrasted 'the so called welfare politics', aimed to preserve capitalism and large income and wealth gaps, with 'socialist welfare politics' ${ }^{74}$ The attribute 'so called' indicates that the authors of the programme were familiar with the expression 'welfare politics'.

However, the 1967 programme of the Social Democratic League of Workers and Small-Scale Farmers and that of the Finnish People's Democratic League did not imply any breakthrough in the understanding of 'welfare politics/policy' or, respectively, 'welfare state'. Hyvinvointivaltio as a characterization of present conditions in Finland appeared in a programme put forward by the Centre Party in 1968, which advocated for more regional policies to ensure 'the constant success of the welfare state'. ${ }^{75}$ In 1974, the Swedish People's Party included 'democratic welfare and equality policies' (demokratisk välfärds-och jämlikhetspolitik) in its programme. However, 
'welfare' as an attribute of the state or its policies gained wider popularity in party programmes only after the concept of welfare state began to mean a historical achievement that had to be defended against external pressures.

In the parties carrying on the socialist tradition, different ways of relating the 'welfare state' to 'socialism' had appeared. In 1968, in Sosialistinen Aikakauslehti (Socialist Journal), put out by the Social Democratic Party, Ahti M. Salonen argued for 'a democratic welfare state' as an alternative to 'socialization', whereas Olavi Jäminki, in turn, identified the welfare state with socialism, which he warmly supported. ${ }^{76}$ However, advocating the welfare state as a substitute for socialism, as the content of socialism or as a step towards socialism did not achieve any central role in Finnish political debates.

In the party congresses of the Social Democratic Party, the concept of welfare state was very rarely used in the 1970s. The guidelines the party congress of 1975 approved for the future elaboration of party programmes mentioned 'the future of the so-called welfare society' ( $n s$. hyvinvointiyhteiskunta) and the associated problems of taxation and redistribution in the list of important issues but only after 'the future of growth-aimed economic policy' and 'the need for a planned economy and the objectives of socialist economic policy'. ${ }^{77}$ In the next party congress, in 1978, a programme for Social Democratic Party politics in the 1980s was approved. 'Welfare state' was not included in the programme. The extension of 'public welfare services' was mentioned in connection with job creation, and 'welfare society' appeared once in a sentence stating that increasing the resources allotted for culture and leisure was an essential feature of a welfare society. The congress repeated the 1975 guidelines for future programme work, including the item concerning 'the future of the so-called welfare society' ${ }^{78}$ 
The critique of the idea of the welfare state became a largely shared feature in Marxist social sciences as they strengthened and developed in Western Europe in the 1970s. 'Welfare state' provided ideological legitimation for a new stage of the bourgeois state. The state in capitalist society was doomed to be incapable of keeping its promise to provide comprehensive welfare, implicated by the very concept of welfare state. In any case, the crisis of capitalism, so evident according to 1970s Marxist diagnoses, was a crisis of the welfare state as well. The extension of state interventions and corporatist forms of interest representation were conceptualized, for example, by means of the theory of state-monopolistic capitalism in particular and not only in Marxist-Leninist variants of Marxism. In Finland, all these aspects of the Marxist critique of the welfare state appeared especially in the follow-up to international theoretical discussions. ${ }^{79}$ However, the limited role of the 'welfare state' as a tool for justifying current circumstances or as an integrative concept for reformist policy objectives implied that it did not work well as a target of effective social critique either.

After the mid 1970s, three books were published that presented, from different Marxist perspectives, general historical accounts of modern Finnish society: the first one was on the history of the labour movement, the second on the past and present of Finnish democracy and the third on Finnish capitalism. The concept of welfare state was almost absent from these texts. ${ }^{80}$ The authors of the last-mentioned book, Suomalainen kapitalismi (Finnish Capitalism, 1979), noticed that the way Pekka Kuusi had in 1961 advocated for 'social democracy' resembled discussions about 'the welfare state' or 'the social state' in many Western European countries. They assessed, however, that such discussion had not enjoyed widespread popularity, and the main reason for this was the fact that 'class antagonisms had in Finland remained relatively strong, making it impossible to talk about a shift to a classless society, as one usually talks in the 
discussion on "the welfare state", The crisis of capitalism in the 1970s had, then, buried any talks about the changed nature of contemporary society, the authors concluded. ${ }^{81}$

In retrospect, the 1970s and 1980s was a period of great welfare-state expansion in Finland. It was also a period in which much of the left-wing critique of the welfare state moved, via international discussions on 'the crisis of the welfare state', to defence of the welfare state against the neoliberal politics of market-based deregulation. Researchers gradually adopted the 'welfare state' as their analytical concept and began to talk about 'a Nordic model' or 'Nordic models'. The lead author of Suomalainen kapitalismi (1979), Pekka Kosonen, completed and published in 1987 his sociological dissertation on the challenges and Nordic models of the welfare state. ${ }^{82}$

\section{Welfare State and Welfare Society}

The era of the expanding welfare state ended in Finland in the early 1990s. Experiences of the emergence of neoliberalism, the globalization of capitalism, the end of the Cold War, the new phase of European integration and the deep economic crisis in Finland all became intertwined. The conclusions implied that much of the previous left-wing critique had turned into a defence of the welfare state, and use of the concept increased at this time. Neoliberal arguments for a radical deregulation emerged in the 1980s and early 1990s, yet by the turn of the century all political parties and interest groups began to talk warmly and sympathetically about the welfare state.

An ambiguous part of these changes was the increased popularity of the concept of a welfare society. It had now and then appeared in descriptions of social and economic conditions, interchangeably being used with that of 'welfare state'. Since the late 1970s, in connection with the diagnoses of 'the crisis of the welfare state' and based on the advice of the OECD, the 
concept of 'welfare society' was internationally adopted as a tool of critique for what was seen as an overly large public sector and a bureaucratic and patronizing welfare state. ${ }^{83}$ The conceptual distinction between state and society was linked with the international emergence of 'civil society' in the 1980s as a concept used to refer to the sphere of private and voluntary actors and activities. In Sweden, the right-wing critics of the welfare state argued that the conceptual confusion of state and society was a sign of the type of social democratic totalitarianism that should be opposed by revitalizing civil society. ${ }^{84}$

The international debate in general and, once again, the Swedish impulses in particular played a role in Finland. The concept of civil society, kansalaisyhteiskunta, was used as a critique of the welfare state, although apparently to a less extent than in Sweden. The concept of welfare society, hyvinvointiyhteiskunta, was made use of by those demanding less state and more market. In the 1994 party programme of a short-lived neoliberal party, the Young Finns, the principal slogan was 'The Activating Welfare Society'. ${ }^{85}$

However, in Finland as well as in other Nordic countries, any attempt to create a political alternative by replacing 'state' with 'society' faced the heavy constraints of old conceptual conventions. 'Welfare society' could actually be used to support the legitimacy of the welfare state because, within the Nordic tradition, 'society' represents the general and public against the particular and private and is a warm and fuzzy term for the state. In Finland, it was, and still is, easy to use 'welfare state' as a concept referring to wellbeing in society and 'welfare society' as a concept referring to functions of the state. Any attempt to operate with the distinction between welfare state and welfare society needs a clarifying explanation: one has to state clearly that he or she is advocating a welfare society in opposition to an excess of governmental intervention (as 
did the Young Finns in 1994) or defending the welfare state against the policies of privatization (as did the small Communist Party in 2004 by supporting 'a democratic welfare state'). ${ }^{86}$

It has been much easier to make use of the ambiguities of the concepts to legitimate one's own political objectives and also conceal controversies regarding the welfare state and, thus, facilitate consensual politics. Thus, in the programmes of the Social Democratic Party, 'welfare state' and 'welfare society' have been used interchangeably.

After preparatory discussions held in the mid 1970s, including those expressing concern about 'the future of the so-called welfare society' in the aforementioned guidelines of the 1975 and 1978 party congresses, the Social Democratic Party adopted a new basic party programme in 1987. In its introduction, the new programme interpreted the contents of earlier programmes in a way that indicated a change concerning the role of the welfare state in the party's historical understanding of itself.

The preceding basic programme had dated back to 1952. While sharply condemning communism as an anti-democratic political force, it had been based on a Marxist view of social transformation and political agency. The inherent laws of capitalist development and the social democratic focus on class-based politics would together lead to a 'socialist planned economy' ${ }^{87}$ The 1952 programme had replaced the first explicitly socialist programme of the Social Democratic Party, adopted in 1903. This programme, following German and Austrian models, had emphasized class struggle, the need to refrain from collaborating with the bourgeoisie and the international character of capitalism and its proletarian, social democratic counter-force. In addition to supporting the main goal of socialism, the 1903 programme presented a list of what were characterized as short-term objectives, including universal suffrage, equality between men and women, free healthcare and education and an eight-hour work day. ${ }^{88}$ 
In the new programme of 1987 , the old objectives were interpreted as guidelines for politics that had been able to move Finland 'in the direction of a welfare state corresponding to social democratic objectives' and 'to take the first steps towards economic democracy'. The concept of welfare state as such did not appear elsewhere in the 1987 programme. The concept of socialism, specified by means of the attribute 'democratic', still played a significant role in the programme, and it not only referred to the 'values' of current social democratic politics but also to the principles of future society. ${ }^{89}$ The programme was still framed via a particular mode of thought, according to which different societal systems were constantly competing in the world, including competing visions of a socialist society. However, the historical account of previous programmes and the ambiguous usage of socialism made it possible to read the programme as suggesting that the welfare state and economic democracy were the final goals of social democratic politics that is, the contents of democratic socialism.

Breaking its tradition of prescribing long-lasting basic programmes, the Social Democratic Party renewed the programme already in 1999. 'Socialism' still appeared in the programme, yet it no longer referred to societal structures but only to 'values' that informed social democratic politics and were 'deeply rooted in the whole of democratic Europe'. In the post-Cold War framing, the option of viewing socialism as an alternative to the capitalist system as well as the possibility of divergent visions of a socialist society were pushed aside. The previous struggle of Social Democrats against 'capitalism and communism' occurred in parallel with their current struggle against 'ultra-liberalism and social conservatism'. The concepts of welfare state and economic democracy were absent from the programme. Instead, 'welfare society' was used in their place. By virtue of its ambiguity, the concept made it possible to view the programme as advocating and defending the welfare state - given the Finnish and wider Nordic use of 'society' 
as a warm synonym for 'state' - or as an announcement that the Social Democrats acknowledged that non-governmental actors as well were important for promoting people's possibilities 'to take part in society' ${ }^{90}$

One can conclude that at the level of party programmes, the Social Democrats clearly avoided drawing any contrasts between 'welfare state' and 'welfare society'. The consensual employment of the ambiguities of these words, especially of 'welfare society', also appears in governmental programmes.

\section{Making Consensual Use of Conceptual Ambiguities}

It was not until 1987 that any Finnish government programme included 'welfare' (hyvinvointi) as part of a compound word. A political coalition was achieved between the Social Democratic Party and the conservative National Coalition Party, with Harri Holkeri from the latter party serving as prime minister. The government declared that it was committed to striving for 'a modern and equal welfare society on our own national basis' ${ }^{91}$

The government broke the tradition of coalitions based on the Social Democrats and the Centre Party. It also ended the more that twenty-year period in which the National Coalition Party had remained outside government. This had been partly due to Urho Kekkonen's, president of Finland from 1956 to 1981, view of what the Finnish-Soviet relationship required. On the other hand, the National Coalition Party had increased its electoral support in the 1970s and 1980s. Many of its voters were salaried employees, often educated women in modestly paid jobs of the expanded welfare state. The party had adopted the view in its programmes of the 1970s that individual choice could be promoted via equality-oriented social and educational policies, and this view was expressed by modifying the 1950s slogan 'social market economy' to read 
'social choice economy' (sosaalinen valintatalous). ${ }^{92}$ The formulation of the 'blue-red' government programme in 1987 on welfare society did not include anything that would not have been problematic for the National Coalition Party. The emphasis on 'our own national basis' in the programme was obviously the party's achievement and was probably meant to take a certain distance from Swedish examples. In a speech to the party faithful in 1987, Holkeri declared that the work of the party would be completed by 'the support of the modern middle class'. It would result in 'a welfare state without patronage' and 'progress without socialism'. ${ }^{93}$

The National Coalition Party and Centre Party formed the next government in 1991, and both were satisfied with just using the word hyvinvointi only once in their programme manifesto, and even then only in the sense of wellbeing ('citizens' health and wellbeing'). 'Welfare society' returned to this category of political documents in 1995, after the deep economic crisis of the early 1990s. The leader of Social Democratic Party, Paavo Lipponen, formed the so-called rainbow government, in which parties ranging from the National Coalition Party to the Greens and the Left Alliance, the recently founded successor to the Finnish People's Democratic League, were represented. In its programme manifesto of 1995, the government noted that 'the core of welfare society' consisted of social and health services, income-related social security and basic social security, which could only be rescued by cutting down on spending: 'the Finnish welfare society will be reformed so that it corresponds to our own resources and the citizens can accept it as just, effective and fair.' The programme also noted that the welfare of citizens would be promoted by lower income taxes and by membership and active participation in the European Union. ${ }^{94}$

Lipponen continued as prime minister in the government formed by the same political coalition after the parliamentary election of 1999. In the government programme, hyvinvointi 
appeared more frequently than it had previously and was associated with what was achieved by encouraging individual initiative as well as with development policies. The programme talked of 'welfare services' (hyvinvointipalvelut), which was the first time any government programme had done so. It was also the first time that a government programme added the word 'Nordic' as an attribute of the 'welfare society': 'The point of departure for the government's social policy is to preserve the Nordic welfare society. ${ }^{95}$

The popularity of 'welfare' and 'welfare society' still increased in the programme of the government formed after the parliamentary election of 2003. After eight years in opposition, the Centre Party, now the largest party, returned to government as part of a coalition that included the Social Democrats and the Swedish People's Party. The government was for a brief period of time lead by Anneli Jäätteenmäki of the Centre Party, then by Matti Vanhanen of the same party. In the introduction to its programme, which now for the first time had an official Swedish version as well, the government combined welfare and security: 'The government will reinforce the security of citizens by continuing the stable line of foreign and security politics of our country and by developing the welfare society, which enjoys widespread support among the citizens.' Moreover, 'welfare state' was now for the first time included in the government programme. According to the introduction of the programme, 'By means of its politics for work, entrepreneurship and solidarity, the government will develop the welfare state and welfare society (hyvinvointivaltio ja -yhteiskunta/välfärdsstat och välfärdssamhälle) that has been during the previous decades successfully built up by wide collaboration' ${ }^{96}$ The expression including both state and society probably reflected an awareness of arguments operating around the distinction between 'welfare state' and 'welfare society', but the programme did not make use of 
this distinction. The focus was on the consensual interpretation of the welfare state/welfare society as a joint national achievement to be defended.

The practice of the two largest parties building the basis for a governmental coalition, adopted since the late 1980s, resulted in 2007 in a coalition government that included the Centre Party, the National Coalition Party, the Greens and the Swedish People's Party, with Matti Vanhanen as prime minister. Its programme manifested the popularity of the vocabulary of welfare/wellbeing (hyvinvointi in Finnish, välfärd or välbefinnande in Swedish). Yet, the programme did not include 'welfare state', only 'welfare society', in its conventionally ambiguous usage. In relation to the series of government programmes, a novelty of this programme was the concept of 'welfare policy' (hyvinvointipolitiikka/välfärdspolitik). It was used as the name for one of several policy areas, notably the area containing social and health policies, working life issues and employment policy. ${ }^{97}$ The administrative usage of the concept was clearly different from the way in which the Swedish Social Democrats had in the 1930s adopted 'welfare politics' as the main concept for integrating their major political objectives. It was also different from how the concept had occasionally appeared in Finland in left-wing efforts to contrast capitalist and socialist welfare politics.

In the parliamentary election of 2011, the populist Finns Party ${ }^{98}$ grew remarkably, and there were now four 'big' parties in the country: the National Coalition Party, the Social Democratic Party, the Finns Party and the Centre Party. After difficult negotiations, a government was formed consisting of the National Coalition Party and the Social Democrats together with the Greens, the Left Alliance, the Swedish People's Party and the Christian Democratic Party. The programme of the government, led by Jyrki Katainen of the National Coalition Party, was written with a rhetoric effectively concealing controversies between the different coalition parties and 
the shock caused by the rise of the anti-EU and anti-immigration Finns Party. The programme began by introducing two expressions that were novelties in Finnish governmental programmes, 'the Nordic welfare state' and 'the Nordic welfare model':

The aim of Jyrki Katainen's government is a caring and successful Finland. Finland will be developed as a Nordic welfare state and as a society that carries its responsibility not only for its own citizens but also at the international level as a part of the Nordic countries, Europe and the world. ${ }^{99}$

The programme continued by convincing the public that 'the Nordic welfare model, based on a high level of employment, competitive economy, equal services and care' had proved to be 'the best societal system'. Hints at impending austerity politics were covered up via such expressions as 'the strengthening of the basic structures of the welfare society' and ensuring 'the sustainable financing of the welfare state'. The concept of welfare policy was used in a similar way as it had appeared in the programme of the preceding government - that is, as an administrative-type name for a particular policy area.

A considerable change in the style in which government programmes were written took place after the parliamentary election of 2015. A government was formed consisting of the Centre Party, the National Coalition Party and the Finns Party. Its programme was written in accordance with the ideals of strategic business management, reflecting the entrepreneurial background of Prime Minister Juha Sipilä of the Centre Party. 'Welfare/wellbeing' appeared in the programme, but 'welfare state' and 'welfare policy/politics' did not. 'Welfare society' was mentioned once, 
namely as the first strength in a table listing the strengths and weaknesses of Finland: 'Finland is a competent, persistent, egalitarian and solution-seeking welfare society.' ${ }^{100}$

While the participation of the Finns Party in the government ${ }^{101}$ corresponds to a Finnish tradition of integration as a means of handling political protest, signs of a fragmenting consensus began to emerge in the middle of the 2010s. ${ }^{102}$ True, the Sipilä government managed to help broker a central agreement between trade unions and employer organizations on measures aimed to improve the competitiveness of Finland by increasing working hours and diminishing some social benefits. However, business life organizations have subsequently even more vigorously argued against a national system of labour market agreements. In the planning of a large reform of social and health services, the Sipilä government is aiming to strengthen the role of private service providers in a way harshly opposed by the red-green opposition. Ideas of a radical deconstruction of public and collective social regulation have been developed in right-wing think-tanks.

However, rescuing the welfare state - or usually interchangeably, the welfare society - is one of the most widely shared arguments in Finnish politics in the 2010s. Those concerned about economic competitiveness or advocating austerity politics motivate these concerns by the necessity to create or rescue resources for the welfare state. The welfare state is used as an argument for restrictive immigration policies as well as for the promotion of labour immigration. Those defending the welfare state against the pressures of globalized capitalism argue that the welfare state actually generates competitive advantages by means of its security networks and risk-sharing systems. Rescuing the welfare state seems to be a goal that sanctifies the means and a means that sanctifies the goal. 


\section{Conclusion: The Welfare State and the National Narrative}

Historiallinen Aikakauskirja (Historical Journal), the leading Finnish scholarly journal of history, published in 1992 a special issue on 'Finland and the Finns' in honour of the $75^{\text {th }}$ anniversary of Finland's national sovereignty. The issue included an article on 'the welfare state in Finland' (Hyvinvointivaltio Suomessa), written by the sociologist Matti Alestalo. He noted that in Finnish vocabularies, hyvinvointivaltio had not achieved so self-evident a position as välfärdsstat had in Swedish. He was obviously referring to a crucial difference between Finland and Sweden: one could hardly have found much evidence on any difference between the vocabularies of Finnishspeaking and Swedish-speaking Finns in this respect. Alestalo was nevertheless motivated to use this concept and argued that Finland no doubt was a welfare state. After describing the building of the welfare state as part of a catch-up process by a Western European and Nordic latecomer, he discussed contemporary tendencies towards a retrenchment of the welfare state and warned about the outcomes of such politics in a society in which the welfare state was deeply rooted in social structures. ${ }^{103}$

Indeed, until the 1980s conceptual tools other than 'welfare state' had mostly been employed to define social problems and solutions in Finland. One effective tool had been the concept of society (yhteiskunta in Finnish, samhälle in Swedish), provided as it was with normative and descriptive capacities and with the properties of being an agent and a target of agency at the same time. It was, and is, often used - as in other Nordic countries - as a synonym for 'state', referring to the state as an ethical entity and thus legitimating governmental interventions into social relations.

'Welfare state', or 'welfare society', was not a must in terms of how Finnish governments chose to define their political agendas. In government programmes, the concept of welfare 
(hyvinvointi, välfärd) was since the 1950s occasionally associated with the redistributive role of the state, but it was only in 1987 that it appeared in a government programme as part of a compound word, namely 'welfare society'. The word 'welfare state' was for the first time included in a Finnish government programme in 2003. The attribute 'Nordic' appeared in front of 'welfare society' in 1999, and in the 2011 government programme Finland was for the first time referred to as 'a Nordic welfare state', representing 'the Nordic welfare model', the best societal system in the world.

In Finland, the concepts of welfare state and welfare society, or welfare politics, never played a major future-oriented role as 'tools for steering historical movement' (Koselleck). 'Welfare state' and 'welfare society', often provided with the attribute 'Nordic', did achieve the position of key concepts in Finnish national narratives, but this only occurred during a phase when they came to refer to the existing valuable achievements of past politics, to be defended and rescued.

Between the $75^{\text {th }}$ anniversary (1992) and the $100^{\text {th }}$ anniversary (2017) of Finland's independence, public constructions of the national past in Finland became based on two major pillars: the wars of the twentieth century and the making of a Nordic welfare state. Sometimes they represent rival ideas about the historical core of national agency but they also become intertwined, not least in how national politics are described as the action of internal will responding to compelling external threats and challenges. Ideological associations with joint efforts during wartime are evoked, for example, by the Finnish word talkoot, meaning that the members of a community voluntarily, out of an internal sense of duty, cooperate in completing an urgent task. The word was constantly used to describe activities on the home front during the World War II. The need for a national talkoot to rescue the welfare state is a favourite phrase 
when advocating many divergent and controversial political objectives, including austerity politics, consensual corporatism or improved competitiveness.

In international scholarly discussion, the concept of competition state emerged in the early 1990s, referring to how the nation states are being reshaped by the imperatives of national competitiveness in a globalized capitalist world. ${ }^{104}$ Likewise in Finland, researchers have accounted for the move from a welfare state to a competition state or from a welfare state to a workfare state. ${ }^{105}$ These accounts critically question a rhetoric that tries to justify any policies as necessary reforms for saving the welfare state or welfare society. At the same time, however, such an understanding of current changes may also contribute to the national(istic) narrative of the welfare state as a long-term national project. In any case, by the mid 2010s an affirmative use of the concept 'competition state' to describe a post-welfare state stage of progress has not gained any significant support in Finland, while, on the other hand, rescuing the welfare state is rarely discussed by envisioning any transnational extension of the concept. ${ }^{106}$

Pauli Kettunen is Professor of Political History at Helsinki University. He has published extensively on topics such as labour relations, the Nordic welfare model, the history of the Finnish welfare state and the conceptual history of politics.

\section{Notes}

1. Reinhart Koselleck, Futures Past: On the Semantics of Historical Time, $2^{\text {nd }}$ ed. (New York: Columbia University Press, 2004), 251. 
2. Cf. the different country chapters in this volume; Pauli Kettunen, 'The Language of Social Politics in Finland', in Daniel Béland and Klaus Petersen (eds), Analysing Social Policy Concepts and Language: Comparative and Transnational Perspectives (Bristol: Policy Press, 2014), 157-76.

3. See the chapter on Sweden in this volume.

4. Matti Alestalo, 'Hyvinvointivaltio Suomessa', Historiallinen Aikakauskirja 90 (1992), 233-34.

5. Pauli Kettunen, 'The Nordic Model and Consensual Competitiveness in Finland', in Anna-Maija Castrén, Markku Lonkila and Matti Peltonen (eds), Between Sociology and History: Essays on Microhistory, Collective Action, and Nation-Building (Helsinki: Finnish Literature Society, 2004), 289-309.

6. This chapter is part of the authors's work in the research project Nationalism and Democracy in the Welfare State, funded in 2013-17 by the Academy of Finland, Research Council for Culture and Society.

7. This three-aspect distinction comes from Quentin Skinner, 'Language and Political Change', in Terence Ball, James Farr and Russel L. Hanson (eds) Political Innovation and Conceptual Change (Cambridge: Cambridge University Press, 1989), 8-22.

8. Helsingin Sanomat, the largest newspaper in modern Finland, has expanded digital access to more recent times, and in a late phase of this study, I made unsystematic use of this material. The POHTIVA database - Poliittisten ohjelmien tietovaranto, http://www.fsd.uta.fi/pohtiva, contains programmes and platforms. The government's online resources, http://valtioneuvosto.fi, has the government declarations.

9. Risto Alapuro, State and Revolution in Finland (Berkeley: University of California Press, 1988); Matti Klinge, The Finnish Tradition: Essays on Structures and Identities in the North of Europe (Helsinki: Finnish Historical Society, 1993); Tuija Pulkkinen, 'One Language, One Mind: The Nationalist Tradition in Finnish Political Culture', in Tuomas M.S. Lehtonen (ed.), Europe's Northern Frontier: Perspectives on Finland's Western Identity (Jyväskylä: PS-Kustannus, 1999), 118-37.

10. Cf. Malcolm Spector and John I. Kitsuse, Constructing Social Problems, $2^{\text {nd }}$ ed. (New Brunswick, NJ: Transaction Publishers, 2001).

11. Lars Trägårdh (ed.), Civilt samhälle kontra offentlig sektor (Stockholm: SNS Förlag, 1995).

12. On this, see the Introduction and the chapter on Sweden in this volume.

13. Manfred Riedel, 'Gesellschaft, bürgerliche', in Otto Brunner, Werner Conze and Reinhart Koselleck (eds), Geschichtliche Grundbegriffe: Historisches Lexikon zur politisch-sozialen Sprache in Deutschland, 8 vols 
(Stuttgart: Klett-Cotta, 1972-97), vol. 2, 719-800; Norberto Bobbio, Democracy and Dictatorship: The Nature and Limits of State Power (Cambridge: Polity Press, 1989); John Heilbron, The Rise of Social Theory (Cambridge: Polity Press, 1995).

14. Kettunen, 'The Nordic Model', 289-309.

15. Pauli Kettunen, 'Yhteiskunta - "Society” in Finnish', Finnish Yearbook of Political Thought 4 (2000), 173-75.

16. Yrjö Koskinen [Y.K.], 'Työväen-seikka 1-3', Kirjallinen Kuukauslehti (1874), 4.

17. Ilkka Liikanen, Fennomania ja kansa: Joukkojärjestäytymisen läpimurto ja Suomalaisen puolueen synty (Helsinki: SHS, 1995).

18. Agathon Meurman, 'Rikkauden jaosta (Esitelmä pidetty joulukuussa 1886)', in Esitelmiä Kansataloudellisessa yhdistyksessä: 1:nen osa. Kansataloudellisen yhdistyksen toimituksia (Porvoo: WSOY, 1893), 30, 35-36.

19. ‘Sosialidemokraattisen puolueen ohjelma: Hyväksytty Forssan puoluekokouksessa 17.-20.8.1903'. POHTIVA Poliittisten ohjelmien tietovaranto, http://www.fsd.uta.fi/pohtiva/ohjelmalistat/SDP/445.

20. Marta Petrusewicz describes similar kinds of periphery perspectives and intellectual activities in the case of Poland, Ireland and the Kingdom of the Two Sicilies, Marta Petrusewicz, 'The Modernisation of the European Periphery; Ireland, Poland, and the Two Sicilies, 1820-1870: Parallell and Connected, Distinct and Comparable', in Deborah Cohen and Maura O'Connor (eds), Comparison and History: Europe in Cross-national Perspective (New York: Routledge, 2004), 145-65.

21. Alexander Gerschenkron, Economic Backwardness in Historical Perspective: A Book of Essays (Cambridge, MA: Belknap Press, 1962), 356-63.

22. George M. Fredrickson, The Comparative Imagination: On the History of Racism, Nationalism, and Social Movements (Berkeley: University of California Press, 2000); Glenda Sluga, 'The Nation and the Comparative Imagination', in Cohen and O'Connor, Comparison and History, 103-15; Benedict Anderson, Imagined Communities: Reflections on the Origin and Spread of Nationalism (London: Verso, 1983).

23. Dieter Senghaas, Von Europa lernen: Entwicklungsgeschichtliche Betrachtungen (Frankfurt am Main: Suhrkamp, 1982); Rune Slagstad, De nasjonale strateger (Oslo: Pax, 1998).

24. Keith Tribe, Governing Economy: The Reformation of German Economic Discourse in 1750-1840 (Cambridge: Cambridge University Press, 1988). 
25. Johan Philip Palmén, Juridisk handbok för medborgerlig bildning (Helsinki: Frenckell, 1859); Johan Philip Palmén, La'in-opillinen käsikirja: Yhteiseksi sivistykseksi (Helsinki: Suomalaisen Kirjallisuuden Seura, 1863). His interest in Von Mohl and his use of välfärdspoliti also appears in 'Helsingfors', Finlands Allmänna Tidning, 19 February 1861.

26.Carl Frithiof Vendell [C.F.V.], 'Den socialdemokratiska skolans angrepp mot egendomen och dess nuvarande fördelning', Album utgifvet af nyländningar 7 (1878), 73.

27. ‘Betydelsen af den franska ministerkrisens lösning', Nya Pressen, 28 June 1899.

28. 'Utlandet: Utrikespolitiska bref', Björneborgs Tidning, 10 December 1901; 'Politisk öfversikt', Wiborgs Nyheter, 10 December 1901.

29. 'Ryssland: Ifrågasatt reorganisation af polisen', Nya Pressen, 8 September 1907; 'Kejsardömet: Polisväsendets omorganisering', Hufvudstadsbladet, 17 November 1907.

30. Palmén, La 'in-opillinen käsikirja, 259.

31. 'Sammanträden: Tekniska föreningen', Nya Pressen, 6-7 September 1883; 'Yleisiä kotimaan uutisia', Ilmarinen, 18 September 1883.

32. Pauli Kettunen, Suojelu, suoritus, subjekti: Työsuojelu teollistuvan Suomen yhteiskunnallisissa ajattelu- ja toimintatavoissa (Helsinki: SHS, 1994), 255-58; Jussi Vauhkonen, Elatuksesta eläkkeeseen: Vanhuudenturva suomalaisessa työnantajapolitiikassa työeläkejärjestelmän rakentamiseen saakka (Helsinki: Helsingin yliopisto, 2016), 75-80.

33. Heimer Björkqvist, Den nationalekonomiska vetenskapens utveckling i Finland intill år 1918 (Turku: Åbo Akademi, 1986), 517-27; Sakari Heikkinen et al., The History of Finnish Economic Thought 1809-1917: History of Learning and Science in Finland 1828-1918 (Helsinki: Finnish Society of Sciences and Letters, 2000), 181.

34. Koskinen, ‘Työväen-seikka', 93-94.

35. Mirja Satka, Making Social Citizenship: Conceptual Practices from the Finnish Poor Law to Professional Social Work (Jyväskylä: SoPhi, 1995), 69-91; Pauli Kettunen, 'Yhteiskunta', in Matti Hyvärinen et al. (eds), Käsitteet liikkeesssä: Suomen poliittisen kulttuurin käsitehistoria (Tampere: Vastapaino, 2003), 191-93.

36. An extreme example is Martti Pihkala, Minkälainen Suomi meidän on luotava? (Jyväskylä: Gummerus, 1918). 37. E.g. Leo Ehrnrooth, Nykyaikainen yhteiskuntapolitiikka (Porvoo: WSOY, 1913). 
38. It is noteworthy that the word politiikka appeared mostly as a compound stem meaning 'policy'. In this way, it did not refer to political activity, or to politics, but to the result of politics. In a general way, this expresses a state-tosociety direction. Politics - i.e. the battles and compromises that precede policies - were rarely called politiikka until the 1920s. The common expression had been valtiollinen toiminta, thus casting politics as 'actions within the state', or as activities pertaining to or taken on behalf of the state. The phrase valtiollinen toiminta lent itself to efforts to achieve or defend valtiollinen kansanvalta (political democracy) and the socialist labour movement was engaged in a valtiollinen luokkataistelu (political class struggle).

39. K.E.P.H., 'Tunne yhteiskuntasi', Ylioppilaslehti 8(14) (1920), 168-69; K.E.P.H.,'YYhteiskunnallista työtä', Ylioppilaslehti 8(24) (1920), 288-89; K.E.P.H. 'Isänmaallisuus ja yhteiskunnallisuus', Ylioppilaslehti 12(13) (1924), 232. The author's name is unknown.

40. Kettunen, 'Yhteiskunta', 198-99.

41. Eino Kuusi, Sosialipolitiikka, 2 vols (Porvoo: WSOY, 1931), 13-14.

42. Slagstad, De nasjonale strateger, 192.

43. 'Suomen Sosialidemokraattisen Puolueen talouspoliittiset suuntaviivat', in Pöytäkirja Suomen Sosialidemokraattisen Puolueen XVI puoluekokouksesta Tampereella 25-18.5.1933 (Helsinki, 1934), 119.

44. E.g. Pekka Railo, Tie yhteiskunnalliseen suunnitelmatalouteen (Tampere: Työväen Sivistysliitto, 1942). - True, at the same time yhteiskunnallinen could still sometimes appear in the context of social policy as a vernacular synonyme of sosiaalinen. Satka, Making Social Citizenship, 158.

45. Kettunen, 'Yhteiskunta', 195-196; Vauhkonen, Elatuksesta eläkkeeseen, 75-80.

46. Armas Nieminen, Mitä on sosiaalipolitiikka: Tutkimus sosiaalipolitiikan käsitteen ja järjestelmän kehityksestä (Helsinki: WSOY, 1955), 43, 95.

47. Pekka Kuusi, 60-luvun sosiaalipolitiikka (Porvoo: WSOY, 1961), 8; Pekka Kuusi, Social Policy for the Sixties: A Plan for Finland (Helsinki: Finnish Social Political Association, 1964), 34.

48. Svenska Folkpartiet, Program för Svenska Folkpartiet i Finland (1964).

49. 'Pääministeri Kaarlo Castrénin hallituksen ohjelma: Castrénin ohjelmapuhe valtioneuvoston yleisessä istunnossa 22.4.1919'. http://valtioneuvosto.fi/tietoa/historiaa/hallitusohjelmat.

50. 'Pääministeri Väinö Tannerin hallituksen ohjelma: Tannerin tiedonanto hallituksen ohjelmasta eduskunnan täysistunnossa 13.12.1926’. http://valtioneuvosto.fiicv/tietoa/historiaa/hallitusohjelmat. 
51. SDP.n eduskuntavaaliteemoja 1907-1999 (Helsinki: Työväen Arkisto, 1999); Museot Finna,

Eduskuntavaalijulisteet 1936. https://museot.finna.fi/Search/Results?lookfor=eduskuntavaalijulisteet+1936.

52. See Edling's chapter on Sweden.

53. 'Pääministeri A.K. Cajanderin ohjelmapuhe valtioneuvoston yleisessä istunnossa 12.3.1937’.

http://valtioneuvosto.fi/tietoa/historiaa/hallitusohjelmat.

54. Pöytäkirja Suomen Sosialidemokraattisen Puoluen XVIII puoluekokouksesta, joka pidettiin Turun

työväenyhdistyksen talossa toukokuun 18-20 päivinä 1939 (Helsinki, 1940), 106-9.

55. 'Pääministeri J.K. Paasikiven III hallituksen ohjelma 17.4.1945'.

http://valtioneuvosto.fi/tietoa/historiaa/hallitusohjelmat.

56. 'Pääministeri Mauno Koiviston hallituksen ohjelma 23.3.1968'.

.http://valtioneuvosto.fi/tietoa/historiaa/hallitusohjelmat.

57. 'Pääministeri Ralf Törngrenin hallituksen ohjelma 6.5.1964'.

http://valtioneuvosto.fi/tietoa/historiaa/hallitusohjelmat.

58. Prime Minister Urho Kekkonen published in 1952 a pamphlet in which he referred to recent news concerning a speech by the English President of the Board of Midland Bank, Lord Hearlech. He had declared that 'social security and the welfare state' (the Finnish translation in Kekkonen's text: sosiaalinen turvallisuus ja hyvinvointivaltio) could only be created by hard work. Urho Kekkonen, Onko maallamme malttia vaurastua? (Helsinki: Otava, 1952). 59. Eino S. Repo (ed.), Toiset pidot tornissa (Jyväskylä: Gummerus, 1954), 242-43; Pauli Kettunen, Globalisaatio ja kansallinen me: Kansallisen katseen historiallinen kritiikki (Tampere: Vastapaino, 2008), 154-55, 242.

60. Yhteishyvävaltio had an association with old Finnish translations of Wohlfahrt and välfärd as they appeared in the compound words Wohlfahrtsausschuss and välfärdsutskottet, the German and Swedish translations of Comité de Salut Public, which had been founded during the French Revolution in 1793. The Finnish translations of German and Swedish texts used the words yhteishyvän valiokunta (committee for common good). This expression was later, during the World War II, used as the name for an information and propaganda committee in the administration overseeing rationing.

61. Sosialidemokraattinen puolue [SDP], ‘Suomen Sosialidemokraattisen Puolueen talouspoliittinen ohjelma perusteluineen 1954', POHTIVA; Helsingin Sanomat, 3 March 1954 (election advertisement of the Social Democratic MP candidates Valdemar Liljeström and Viljo Korhonen). 
62. Pöytäkirja Suomen Sosialidemokraattisen Puolueen XXIII puoluekokouksesta Helsingissä 3.-6.6.1955 (Helsinki, 1955), 39-41.

63. Helsingin Sanomat, 1 February 1962; Päivi Uljas, Hyvinvointivaltion läpimurto: Pienviljelyhegemonian rapautumisen, kansalaisliikehdinnän ja poliittisen murroksen keskinäiset suhteet suomalaisessa yhteiskunnassa 1950-luvun loppuvuosina (Helsinki: Into, 2012), 235.

64. Kansallinen Kokoomus, 'Kansallisen Kokoomuksen yleisohjelma: Vahvistettu puoluekokouksessa Helsingissä 28-29.4.1957’; 'Kansallisen Kokoomuksen kunnallisohjelma: Vahvistettu Kansallisen Kokoomuksen valtuuston syyskokouksessa 26.9.1959', POHTIVA; Jyrki Smolander, Suomalainen oikeisto ja 'kansankoti': Kansallisen Kokoomuksen suhtautuminen pohjoismaiseen hyvinvointivaltiomalliin jälleenrakennuskaudelta konsensusajan alkuun (Helsinki: Suomalaisen Kirjallisuuden Seura, 2003), 118-36.

65. Kansallinen Kokoomus, 'Kokoomuksen Poliittinen Toimintaohjelma 1966 - Kohti huomispäivän yhteiskuntaa', POHTIVA.

66. Smolander, Suomalainen oikeisto, 161.

67. Smolander, Suomalainen oikeisto, 310-312.

68. Eino Sormunen, Hyvinvointivaltio ja henkinen elämä: Eräitä ajankohtaisia ongelmia (Pieksämäki: Suomen Kirkon Sisälähetysseura, 1958); Pirjo Markkola, 'The Lutheran Nordic Welfare States', in Pauli Kettunen and Klaus Petersen (eds), Beyond Welfare State Models: Transnational Historical Perspectives to Social Policy (Cheltenham: Edward Elgar, 2011), 113.

69. Pekka Kuusi, 'Hyvinvointivaltion ideologia', in Kauko Sipponen and Jouko Hulkko (eds),

Yhteiskuntasuunnittelu (Helsinki: Suomalaisuuden liitto, 1963); Erkki Tuomioja, Pekka Kuusi: Alkoholipoliitikko. Sosiaalipoliitikko. Ihmiskuntapoliitikko (Helsinki: Tammi, 1996), 139.

70. Urpo Harva, Ihminen hyvinvointivaltiossa (Helsinki: Kirjayhtymä, 1964).

71. Facta-10-osainen tietosanakirja, 3 GAS-ISL (Helsinki: WSOY, 1969), 765.

72. Suomen Kansan Demokraattisen Liitto, 'Suomen Kansan Demokraattisen Liitton Periaateohjelma: Hyväksytty SKDL:n 8.liittokokouksessa Helsingissä 13.5.-15.5.1967’, POHTIVA.

73. Jouko Siipi, Ryysyrannasta hyvinvointivaltioon: Sosiaalinen kehitys itsenäisessä Suomessa (Helsinki: Tammi, 1967). 
74. Työväen ja Pienviljelijäin Sosialidemokraattinen liitto, 'Työväen ja Pienviljelijäin Sosialidemokraattinen Liitto: Periaateohjelma: Hyväksytty III varsinaisessa puoluekokouksessa Kiljavalla 4.6.1967’, POHTIVA.

75. Keskustapuolue, 'Keskustapuolueen yleisohjelma: Hyväksytty 15.-16.6.1968 Tampereella pidetyssä puoluekokouksessa', POHTIVA.

76. Ahti M. Salonen, 'Sosialisoinnista ja pääomavirtojen valvonnasta', Sosialistinen Aikakauslehti 24(1) (1968), 2629; Olavi Jäminki, 'Länsimainen sosialidemokratia ja sosialismi', Sosialistinen Aikakauslehti 24(2) (1968), 32-34. I am grateful to Ilkka Kärrylä for informing me about this debate.

77. SDP:n XXX puoluekokouksen päätökset: SDP:n XXX puoluekokous pidettiin Jyväskylässä 5.-8.6.1975 (Joensuu: Kansan Voima, 1975), 50.

78. Pöytäkirja Suomen Sosialidemokraattisen Puolueen XXXI puoluekokouksesta Espoossa 1978 (Joensuu: Kansan Voima, 1979), 124-135, 355-359, 433, 484-492; SDP, ‘Sosialidemokratian suunta: SDP:n tienviitat 1980-luvulle: Hyväksytty SDP:n 31. puoluekokouksessa v. 1978 Espoossa', POHTIVA.

79. E.g. Raimo Blom, Yhteiskuntateoria ja valtio (Tampere: Vastapaino, 1983); Risto Eräsaari, Sosiaalivaltio ja sosiaalipolitiikan itseymmärrys (Helsinki: Sosiaalipoliittinen yhdistys, 1984).

80. Lauri Haataja et al. (eds), Suomen työväenliikkeen historia (Helsinki: Työväen Sivistysliitto, 1976); Jukka Gronow, Pertti Klemola and Juha Partanen, Demokratian rajat ja rakenteet: Tutkimus suomalaisesta hallitsemistavasta ja sen taloudellisesta perustasta (Helsinki: WSOY, 1977); Pekka Kosonen et al., Suomalainen kapitalismi: Tutkimus yhteiskunnallisesta kehityksestä ja sen ristiriidoista sodanjälkeisessä Suomessa (Helsinki: Love Kirjat, 1979).

81. 'Kovin laajasti tällainen keskustelu ei kuitenkaan ulottunut Suomeen. Syynä oli paitsi edellä mainitut kehityksen ristiriitaiset piirteet myös yleisemmin se, että luokkavastakohdat pysyivät Suomessa suhteellisen voimakkaina eivätkä mahdollistaneet puhumista luokattomaan yhteiskuntaan siirtymisestä, jollaista keskustelu 'hyvinvointivaltiosta' paljolti on. / Kriisi ja lama 70-luvun jälkipuoliskolla ovat haudanneet puheet yhteiskunnan luonteen muuttumisesta.' Kosonen et al., Suomalainen kapitalismi, 320-21.

82. Pekka Kosonen, Hyvinvointivaltion haasteet ja pohjoismaiset mallit (Tampere: Vastapaino, 1987).

83. Matthieu Leimgruber, 'The Embattled Standard-bearer of Social Insurance and its Challenger: The ILO, the OECD, and the Crisis of the Welfare State (1975-1985)', in Sandrine Kott and Joëlle Droux (eds), Globalizing 
Social Rights: The International Labour Organization and Beyond (Basingstoke and Geneva: Palgrave Macmillan and the ILO, 2013), 293-309.

84. Trägårdh, Civilt samhälle.

85. Nuorsuomalainen Puolue, 'Nuorsuomalainen Puolue r.p. Yleisohjelma hyväksytty Helsingissä 6. joulukuuta 1994', POHTIVA.

86. Suomen Kommunistinen Puolue, 'Toimintaan demokraattisen hyvinvointiyhteiskunnan puole sta - SKP:n kunnallisohjelma' (2004), POHTIVA.

87. SDP, ‘Suomen Sosialidemokraattisen Puolueen periaateohjelma perusteluineen: Hyväksytty XXII:ssa puoluekokouksessa 22.-24.5.1952', POHTIVA.

88. SDP, 'Sosialidemokraattisen puolueen ohjelma: Hyväksytty Forssan puoluekokouksessa 17.-20.8.1903', POHTIVA.

89. SDP, ‘Periaateohjelma hyväksytty SDP:n 34. puoluekokouksessa Helsingissä 4.-7.6.1987’, POHTIVA.

90. SDP, 'Sosialidemokratian periaatteet: Hyväksytty XXXVIII puoluekokouksessa Turussa 29.5.1999', POHTIVA.

91. 'Pääministeri Harri Holkerin hallituksen ohjelma 30.4.1987'.

http://valtioneuvosto.fi/tietoa/historiaa/hallitusohjelmat.

92. Jouko Marttila, Hillitty markkinatalous: Kokoomuksen ja SDP:n talouspoliittinen lähentyminen ja hallitusyhteistyö 1980-luvulla (Jyväskylä: Docendo, 2016), 85-93.

93. Marttila, Hillitty markkinatalous, 168.

94. 'Pääministeri Paavo Lipposen hallituksen ohjelma 13.4.1995'.

http://valtioneuvosto.fi/tietoa/historiaa/hallitusohjelmat.

95. 'Pääministeri Paavo Lipposen II hallituksen ohjelma 15.4.1999'.

http://valtioneuvosto.fi/tietoa/historiaa/hallitusohjelmat.

96. 'Pääministeri Anneli Jäätteenmäen hallituksen ohjelma 17.4.2003'.

http://valtioneuvosto.fi/tietoa/historiaa/hallitusohjelmat.

97. 'Pääministeri Matti Vanhasen II hallituksen ohjelma 19.4.2007'.

http://valtioneuvosto.fi/tietoa/historiaa/hallitusohjelmat.

98. The most usual English translation of the party's name Perussuomalaiset had been 'The True Finns'. In 2011 the party announced that they would be 'The Finns' in their international communication. 
99. 'Pääministeri Jyrki Kataisen hallituksen ohjelma 22.6.2011'.

http://valtioneuvosto.fi/tietoa/historiaa/hallitusohjelmat.

100. 'Suomi on osaava, sisukas, tasa-arvoinen ja ratkaisukeskeinen hyvinvointiyhteiskunta'. 'Pääministeri Juha Sipilän hallituksen ohjelma 29.5.2015'. http://valtioneuvosto.fi/tietoa/historiaa/hallitusohjelmat.

101. In June 2017, a dramatic split took place within the Finns Party. After the election of a new chair representing the most anti-immigration wing in the party, the majority of its MPs and all ministers left the party and founded a new one, the Blue Future. It was now a coalition partner in Sipilä's government, whereas the Finns Party moved to opposition.

102. Kettunen, 'The Nordic Model'; Johanna Rainio-Niemi, 'Small State Cultures of Consensus: State Traditions and Consensus-Seeking in the Neo-corporatist and Neutrality Policies in Post-1945 Austria and Finland' (Helsinki: Dissertation, Faculty of Social Sciences, University of Helsinki, 2008).

103. Alestalo, 'Hyvinvointivaltio Suomessa', 252.

104. Philip G. Cerny, The Changing Architecture of Politics: Structure, Agency, and the Future of the State (London: Sage Publications, 1990).

105. Kettunen, 'The Nordic Model', 302-6; Anu Kantola and Johannes Kananen, 'Seize the Moment: Financial Crisis and the Making of the Finnish Competition State', New Political Economy 18(6) (2013), 811-26; Johannes Kananen (ed.), Kilpailuvaltion kyydissä: Suomen hyvinvointimallin tulevaisuus (Helsinki: Gaudeamus, 2017). 106. In Denmark, the Social Democratic Minister of Finance, Bjarne Corydon, in 2013 acknowledged the 'competition state' as a good concept for describing 'contemporary national politics', 'Corydon: Konkurrencestat er ny velfærdsstat', Politiken, 23 August 2013. Given the lively interest of many Finnish debaters in the supposedly competitive aspects of 'the Danish model', it would not be surprising if his example - supported by such Danish scholars as Ove K. Pedersen - encourages some Finnish politicians as well. 


\section{References}

Primary Sources

'Betydelsen af den franska ministerkrisens lösning', Nya Pressen, 28 June 1899.

Björkqvist, Heimer, Den nationalekonomiska vetenskapens utveckling i Finland intill år 1918 (Turku: Åbo Akademi, 1986).

Blom, Raimo, Yhteiskuntateoria ja valtio (Tampere: Vastapaino, 1983).

'Corydon: Konkurrencestat er ny velfærdsstat', Politiken, 23 August 2013.

Ehrnrooth, Leo, Nykyaikainen yhteiskuntapolitiikka (Porvoo: WSOY, 1913).

Eräsaari, Risto, Sosiaalivaltio ja sosiaalipolitiikan itseymmärrys (Helsinki: Sosiaalipoliittinen yhdistys, 1984).

Gronow, Jukka, Pertti Klemola and Juha Partanen, Demokratian rajat ja rakenteet: Tutkimus suomalaisesta hallitsemistavasta ja sen taloudellisesta perustasta (Helsinki: WSOY, 1977).

Haataja Lauri, et al., (eds), Suomen työväenliikkeen historia (Helsinki: Työväen Sivistysliitto, 1976).

Harva, Urpo, Ihminen hyvinvointivaltiossa (Helsinki: Kirjayhtymä, 1964).

'Helsingfors', Finlands Allmänna Tidning, 19 February 1861.

'Hyvinvointivaltio', Facta-10-osainen tietosanakirja, vol. 3 (Helsinki: WSOY, 1969), 765.

Jäminki, Olavi, 'Länsimainen sosialidemokratia ja sosialismi', Sosialistinen Aikakauslehti 24(2) (1968), 32-34.

Kansallinen Kokoomus, 'Kansallisen Kokoomuksen yleisohjelma: Vahvistettu puoluekokouksessa Helsingissä 28-29.4.1957'. Retrieved 27 April 2017 from POHTIVA - Poliittisten ohjelmien tietovaranto, http://www.fsd.uta.fi/pohtiva/ohjelmalistat/KOK/120. 
Kansallinen Kokoomus, 'Kansallisen Kokoomuksen kunnallisohjelma: Vahvistettu Kansallisen Kokoomuksen valtuuston syyskokouksessa 26.9.1959'. Retrieved 20 April 2017 from POHTIVA - Poliittisten ohjelmien tietovaranto http://www.fsd.uta.fi/pohtiva/ohjelmalistat/KOK/26.

Kansallinen Kokoomus, 'Kokoomuksen Poliittinen Toimintaohjelma 1966 - Kohti huomispäivän yhteiskuntaa'. Retrieved 21 April 2017 from POHTIVA - Poliittisten ohjelmien tietovaranto, http://www.fsd.uta.fi/pohtiva/ohjelmalistat/KOK/90.

‘Kejsardömet: Polisväsendets omorganisering', Hufvudstadsbladet, 17 November 1907.

Kekkonen, Urho, Onko maallamme malttia vaurastua? (Helsinki: Otava, 1952).

K.E.P.H., 'Tunne yhteiskuntasi', Ylioppilaslehti 8(14) (1920), 168-69.

K.E.P.H.,'Yhteiskunnallista työtä', Ylioppilaslehti 8(24) 1920, 288-89.

K.E.P.H. 'Isänmaallisuus ja yhteiskunnallisuus', Ylioppilaslehti 12(13) (1924), 232.

Keskustapuolue, 'Keskustapuolueen yleisohjelma: Hyväksytty 15.-16.6.1968 Tampereella pidetyssä puoluekokouksessa'. Retrieved 27 April 2017 from POHTIVA - Poliittisten ohjelmien tietovaranto, http://www.fsd.uta.fi/pohtiva/ohjelmalistat/KESKP/264.

Koskinen, Yrjö [Y.K.], 'Työväen-seikka 1-3', Kirjallinen Kuukauslehti (1874), 1-9, 91-102, 195$213,219-27$.

Kosonen, Pekka, Hyvinvointivaltion haasteet ja pohjoismaiset mallit (Tampere: Vastapaino, 1987).

Kosonen, Pekka et al., Suomalainen kapitalismi: Tutkimus yhteiskunnallisesta kehityksestä ja sen ristiriidoista sodanjälkeisessä Suomessa (Helsinki: Love Kirjat, 1979).

Kuusi, Eino, Sosialipolitiikka, 2 vols (Porvoo: WSOY, 1931).

Kuusi, Pekka, 60-luvun sosiaalipolitiikka (Porvoo: WSOY, 1961).

Kuusi, Pekka, 'Hyvinvointivaltion ideologia', in Kauko Sipponen and Jouko Hulkko (eds), Yhteiskuntasuunnittelu (Helsinki: Suomalaisuuden liitto, 1963), 125-35. 
Kuusi, Pekka, Social Policy for the Sixties: A Plan for Finland (Helsinki: Finnish Social Political Association, 1964).

Meurman, Agathon, 'Rikkauden jaosta (Esitelmä pidetty joulukuussa 1886)', in Esitelmiä Kansataloudellisessa yhdistyksessä: 1:nen osa. Kansataloudellisen yhdistyksen toimituksia (Porvoo: WSOY, 1893), 25-40.

Museot Finna, Eduskuntavaalijulisteet 1936. Retrieved 16 April 2017 from https://museot.finna.fi/Search/Results?lookfor=eduskuntavaalijulisteet+1936.

Nieminen, Armas, Mitä on sosiaalipolitiikka: Tutkimus sosiaalipolitiikan käsitteen ja järjestelmän kehityksestä (Helsinki: WSOY, 1955).

Nuorsuomalainen Puolue, 'Nuorsuomalainen Puolue r.p. Yleisohjelma hyväksytty Helsingissä 6. joulukuuta 1994'. Retrieved 27 April 2017 from POHTIVA - Poliittisten ohjelmien tietovaranto, http://www.fsd.uta.fi/pohtiva/NSP/325.

'Pääministeri A.K. Cajanderin ohjelmapuhe valtioneuvoston yleisessä istunnossa 12.3.1937'. Retrieved 2 May 2017 from http://valtioneu vosto.fi/tietoa/historiaa/hallitusohjelmat.

'Pääministeri Anneli Jäätteenmäen hallituksen ohjelma 17.4.2003', Retrieved 4 May 2017 from http://valtioneuvosto.fi/tietoa/historiaa/hallitusohjelmat.

'Pääministeri Harri Holkerin hallituksen ohjelma 30.4.1987'. Retrieved 4 May 2017 from http://valtioneuvosto.fi/tietoa/historiaa/hallitusohjelmat.

'Pääministeri J.K. Paasikiven III hallituksen ohjelma 17.4.1945'. Retrieved 2 May 2017 from http://valtioneuvosto.fi/tietoa/historiaa/hallitusohjelmat.

'Pääministeri Juha Sipilän hallituksen ohjelma 29.5.2015'. Retrieved 4 May 2017 from http://valtioneuvosto.fi/tietoa/historiaa/hallitusohjelmat. 
'Pääministeri Jyrki Kataisen hallituksen ohjelma 22.6.2011'. Retrieved 4 May 2017 from http://valtioneuvosto.fi/tietoa/historiaa/hallitusohjelmat.

'Pääministeri Kaarlo Castrénin hallituksen ohjelma: Castrénin ohjelmapuhe valtioneu voston yleisessä istunnossa 22.4.1919'. Retrieved 2 May 2017 from http://valtioneuvosto.fi/tietoa/historiaa/hallitusohjelmat.

'Pääministeri Matti Vanhasen II hallituksen ohjelma 19.4.2007'. http://valtioneuvosto.fi/tietoa/historiaa/hallitusohjelmat.

'Pääministeri Mauno Koiviston hallituksen ohjelma 23.3.1968'. Retrieved 2 May 2017 from http://valtioneuvosto.fi/tietoa/historiaa/hallitusohjelmat.

'Pääministeri Paavo Lipposen hallituksen ohjelma 13.4.1995'. Retrieved 4 May 2017 from http://valtioneuvosto.fi/tietoa/historiaa/hallitusohjelmat.

'Pääministeri Paavo Lipposen II hallituksen ohjelma 15.4.1999'. Retrieved 4 May 2017 from http://valtioneuvosto.fi/tietoa/historiaa/hallitusohjelmat.

'Pääministeri Ralf Törngrenin hallituksen ohjelma 6.5.1964'. Retrieved 2 May 2017 from http://valtioneuvosto.fi/tietoa/historiaa/hallitusohjelmat.

'Pääministeri Väinö Tannerin hallituksen ohjelma: Tannerin tiedonanto hallituksen ohjelmasta eduskunnan täysistunnossa 13.12.1926'. Retrieved 2 May 2017 from http://valtioneuvosto.fiicv/tietoa/historiaa/hallitu sohjelmat.

Palmén, Johan Philip, Juridisk handbok för medborgerlig bildning (Helsinki: Frenckell, 1859). Palmén, Johan Philip, La 'in-opillinen käsikirja: Yhteiseksi sivistykseksi (Helsinki: Suomalaisen Kirjallisuuden Seura, 1863).

Pihkala, Martti, Minkälainen Suomi meidän on luotava? (Jyväskylä: Gummerus, 1918). POHTIVA - Poliittisten ohjelmien tietovaranto, http://www.fsd.uta.fi/pohtiva. 
'Politisk öfversikt', Wiborgs Nyheter, 10 December 1901.

Pöytäkirja Suomen Sosialidemokraattisen Puolueen XXIII puoluekokouksesta Helsingissä 3.6.6.1955 (Helsinki, 1955).

Pöytäkirja Suomen Sosialidemokraattisen Puolueen XVIII puoluekokouksesta, joka pidettiin Turun työväenyhdistyksen talossa toukokuun 18-20 päivinä 1939 (Helsinki, 1940).

Pöytäkirja Suomen Sosialidemokraattisen Puolueen XXXI puoluekokouksesta Espoossa 1978 (Joensuu: Kansan Voima, 1979).

Railo, Pekka, Tie yhteiskunnalliseen suunnitelmatalouteen (Tampere: Työväen Sivistysliitto, 1942). ‘Ryssland: Ifrågasatt reorganisation af polisen', Nya Pressen, 8 September 1907.

Salonen, Ahti M., 'Sosialisoinnista ja pääomavirtojen valvonnasta', Sosialistinen Aikakauslehti 24(1) (1968), 26-29.

'Sammanträden: Tekniska föreningen', Nya Pressen, 6-7 September 1883.

Siipi, Jouko, Ryysyrannasta hyvinvointivaltioon: Sosiaalinen kehitys itsenäisessä Suomessa (Helsinki: Tammi, 1967).

Sormunen, Eino, Hyvinvointivaltio ja henkinen elämä: Eräitä ajankohtaisia ongelmia (Pieksämäki: Suomen Kirkon Sisälähetysseura, 1958).

'Sosialidemokraattisen puolueen ohjelma: Hyväksytty Forssan puoluekokouksessa 17.-20.8.1903'. Retrieved 20 April 2017 from POHTIVA - Poliittisten ohjelmien tietovaranto, http://www.fsd.uta.fi/pohtiva/ohjelmalistat/SDP/445.

Suomen Kansan Demokraattisen Liitto, 'Suomen Kansan Demokraattisen Liitton Periaateohjelma: Hyväksytty SKDL:n 8.liittokokouksessa Helsingissä 13.5.-15.5.1967’. Retrieved 27 April 2017 from POHTIVA - Poliittisten ohjelmien tietovaranto, http://www.fsd.uta.fi/pohtiva/ohjelmalistat/SKDL/626. 
Suomen Kommunistinen Puolue, 'Toimintaan demokraattisen hyvinvointiyhteiskunnan puole sta SKP:n kunnallisohjelma’ (2004). Retrieved 20 April 2017 from POHTIVA - Poliittisten ohjelmien tietovaranto, http://www.fsd.uta.fi/pohtiva/SKP/742.

Suomen Sosialidemokraattinen Puolue, 'Suomen Sosialidemokraattisen Puolueen periaateohjelma perusteluineen: Hyväksytty XXII:ssa puoluekokouksessa 22.-24.5.1952'. Retrieved 20 April 2017 from POHTIVA - Poliittisten ohjelmien tietovaranto, http://www.fsd.uta.fi/pohtiva/SDP/449.

Suomen Sosialidemokraattinen puolue, 'Suomen Sosialidemokraattisen Puolueen talouspoliittinen ohjelma perusteluineen 1954'. Retrieved 20 April 2017 from POHTIVA - Poliittisten ohjelmien tietovaranto http://www.fsd.uta.fi/pohtiva/ohjelmalistat/SDP/464.

Suomen Sosialidemokraattinen Puolue, SDP:n XXX puoluekokouksen päätökset: SDP:n XXX puoluekokous pidettiin Jyväskylässä 5.-8.6.1975 (Joensuu: Kansan Voima, 1975).

Suomen Sosialidemokraattinen Puolue, 'Periaateohjelma hyväksytty SDP:n 34. puoluekokouksessa Helsingissä 4.-7.6.1987'. Retrieved 20 April 2017 from POHTIVA - Poliittisten ohjelmien tietovaranto, http://www.fsd.uta.fi/pohtiva/ohjelmalistat/SDP/450.

Suomen Sosialidemokraattinen Puolue, SDP.n eduskuntavaaliteemoja 1907-1999 (Helsinki: Työväen Arkisto, 1999).

Suomen Sosialidemokraattinen Puolue, 'Sosialidemokratian periaatteet: Hyväksytty XXXVIII puoluekokouksessa Turussa 29.5.1999'. Retrieved 20 April 2017 from POHTIVA - Poliittisten ohjelmien tietovaranto, http://www.fsd.uta.fi/pohtiva/ohjelmalistat/SDP/451.

Suomen Sosialidemokraattinen Puolue, 'Sosialidemokratian suunta: SDP:n tienviitat 1980-luvulle: Hyväksytty SDP:n 31. puoluekokouksessa v. 1978 Espoossa’. Retrieved 21 April 2017 from 
'Suomen Sosialidemokraattisen Puolueen talouspoliittiset suuntaviivat', in Pöytäkirja Suomen Sosialidemokraattisen Puolueen XVI puoluekokouksesta Tampereella 25-18.5.1933 (Helsinki, 1934), 119-28.

Svenska Folkpartiet, Program för Svenska Folkpartiet i Finland (1964). Retrieved 27 April 2017 from POHTIVA - Poliittisten ohjelmien tietovaranto, http://www.fsd.uta.fi/pohtiva/ohjelmalistat/SFP/566.

Trägårdh, Lars (ed.), Civilt samhälle kontra offentlig sektor (Stockholm: SNS Förlag, 1995).

Tuomioja, Erkki, Pekka Kuusi: Alkoholipoliitikko. Sosiaalipoliitikko. Ihmiskuntapoliitikko (Helsinki: Tammi, 1996).

Työväen ja Pienviljelijäin Sosialidemokraattinen liitto, 'Työväen ja Pienviljelijäin Sosialidemokraattinen Liitto: Periaateohjelma: Hyväksytty III varsinaisessa puoluekokouksessa Kiljavalla 4.6.1967’. Retrieved 24 April 2017 from POHTIVA - Poliittisten ohjelmien tietovaranto, http://www.fsd.uta.fi/pohtiva/ohjelmalistat/TPSL/379.

'Utlandet: Utrikespolitiska bref', Björneborgs Tidning, 10 December 1901.

Vendell, Carl Frithiof [C.F.V.], 'Den socialdemokratiska skolans angrepp mot egendomen och dess nuvarande fördelning', Album utgifvet af nyländningar 7 (1878), 68-89.

'Yleisiä kotimaan uutisia', Ilmarinen, 18 September 1883.

Secondary Sources

Alapuro, Risto, State and Revolution in Finland (Berkeley: University of California Press, 1988). Alestalo, Matti, 'Hyvinvointivaltio Suomessa', Historiallinen Aikakauskirja 90 (1992), 233-42. Anderson, Benedict, Imagined Communities: Reflections on the Origin and Spread of Nationalism (London: Verso, 1983). 
Bobbio, Norberto, Democracy and Dictatorship: The Nature and Limits of State Power (Cambridge: Polity Press, 1989).

Cerny, Philip G., The Changing Architecture of Politics: Structure, Agency, and the Future of the State (London: Sage Publications, 1990).

Fredrickson, George M., The Comparative Imagination: On the History of Racism, Nationalism, and Social Movements (Berkeley: University of California Press, 2000).

Gerschenkron, Alexander, Economic Backwardness in Historical Perspective: A Book of Essays (Cambridge, MA: Belknap Press, 1962), 356-63.

Heikkinen Sakari et al., The History of Finnish Economic Thought 1809-1917: History of Learning and Science in Finland 1828-1918 (Helsinki: Finnish Society of Sciences and Letters, 2000).

Heilbron, John, The Rise of Social Theory (Cambridge: Polity Press, 1995).

Kananen, Johannes (ed.), Kilpailuvaltion kyydissä: Suomen hyvinvointimallin tulevaisuus (Helsinki: Gaudeamus, 2017).

Kantola, Anu, and Johannes Kananen, 'Seize the Moment: Financial Crisis and the Making of the Finnish Competition State', New Political Economy 18(6) (2013), 811-26.

Kettunen, Pauli, Suojelu, suoritus, subjekti: Työsuojelu teollistuvan Suomen yhteiskunnallisissa ajattelu- ja toimintatavoissa (Helsinki: SHS, 1994).

Kettunen, Pauli, 'Yhteiskunta - "Society” in Finnish', Finnish Yearbook of Political Thought 4 (2000), 159-97.

Kettunen, Pauli, 'Yhteiskunta', in Matti Hyvärinen et al. (eds), Käsitteet liikkeesssä: Suomen poliittisen kulttuurin käsitehistoria (Tampere: Vastapaino, 2003), 167-212. 
Kettunen, Pauli, 'The Nordic Model and Consensual Competitiveness in Finland', in Anna-Maija Castrén, Markku Lonkila and Matti Peltonen (eds), Between Sociology and History: Essays on Microhistory, Collective Action, and Nation-Building (Helsinki: Finnish Literature Society, 2004), 289-309.

Kettunen, Pauli, Globalisaatio ja kansallinen me: Kansallisen katseen historiallinen kritiikki (Tampere: Vastapaino, 2008).

Kettunen, Pauli, 'The Language of Social Politics in Finland', in Daniel Béland and Klaus Petersen (eds), Analysing Social Policy Concepts and Language: Comparative and Transnational Perspectives (Bristol: Policy Press, 2014), 157-76.

Klinge, Matti, The Finnish Tradition: Essays on Structures and Identities in the North of Europe (Helsinki: Finnish Historical Society, 1993).

Koselleck, Reinhart, Futures Past: On the Semantics of Historical Time, $2^{\text {nd }}$ ed. (New York: Columbia University Press, 2004).

Leimgruber, Matthieu, 'The Embattled Standard-bearer of Social Insurance and its Challenger: The ILO, the OECD, and the Crisis of the Welfare State (1975-1985)', in Sandrine Kott and Joëlle Droux (eds), Globalizing Social Rights: The International Labour Organization and Beyond (Basingstoke and Geneva: Palgrave Macmillan and the ILO, 2013), 293-309.

Liikanen, Ilkka, Fennomania ja kansa: Joukkojärjestäytymisen läpimurto ja Suomalaisen puolueen synty (Helsinki: SHS, 1995).

Markkola, Pirjo, 'The Lutheran Nordic Welfare States', in Pauli Kettunen and Klaus Petersen (eds), Beyond Welfare State Models: Transnational Historical Perspectives to Social Policy (Cheltenham: Edward Elgar, 2011), 102-18. 
Marttila, Jouko, Hillitty markkinatalous: Kokoomuksen ja SDP:n talouspoliittinen lähentyminen ja hallitusyhteistyö 1980-luvulla (Jyväskylä: Docendo, 2016).

Petrusewicz, Marta, 'The Modernisation of the European Periphery; Ireland, Poland, and the Two Sicilies, 1820-1870: Parallell and Connected, Distinct and Comparable', in Deborah Cohen and Maura O'Connor (eds), Comparison and History: Europe in Cross-national Perspective (New York: Routledge, 2004), 145-65.

Pulkkinen, Tuija, 'One Language, One Mind: The Nationalist Tradition in Finnish Political Culture', in Tuomas M.S. Lehtonen (ed.), Europe's Northern Frontier: Perspectives on Finland's Western Identity (Jyväskylä: PS-Kustannus, 1999), 118-37.

Rainio-Niemi, Johanna, 'Small State Cultures of Consensus: State Traditions and ConsensusSeeking in the Neo-corporatist and Neutrality Policies in Post-1945 Austria and Finland' (Helsinki: Dissertation, Faculty of Social Sciences, University of Helsinki, 2008).

Repo, Eino S. (ed.), Toiset pidot tornissa (Jyväskylä: Gummerus, 1954).

Riedel, Manfred, 'Gesellschaft, bürgerliche', in Otto Brunner, Werner Conze and Reinhart Koselleck (eds), Geschichtliche Grundbegriffe: Historisches Lexikon zur politisch-sozialen Sprache in Deutschland, vol. 2 (Stuttgart: Klett-Cotta, 1975), 719-800.

Satka, Mirja, Making Social Citizenship: Conceptual Practices from the Finnish Poor Law to Professional Social Work (Jyväskylä: SoPhi, 1995).

Senghaas, Dieter, Von Europa lernen: Entwicklungsgeschichtliche Betrachtungen (Frankfurt am Main: Suhrkamp, 1982).

Skinner, Quentin, 'Language and Political Change', in Terence Ball, James Farr and Russel L. Hanson (eds), Political Innovation and Conceptual Change (Cambridge: Cambridge University Press, 1989), 6-23. 
Slagstad, Rune, De nasjonale strateger (Oslo: Pax, 1998).

Sluga, Glenda, 'The Nation and the Comparative Imagination', in Deborah Cohen and Maura O’Connor (eds), Comparison and History: Europe in Cross-national Perspective (New York: Routledge, 2004), 103-15.

Smolander, Jyrki, Suomalainen oikeisto ja 'kansankoti': Kansallisen Kokoomuksen suhtautuminen pohjoismaiseen hyvinvointivaltiomalliin jälleenrakennuskaudelta konsensusajan alkuun (Helsinki: Suomalaisen Kirjallisuuden Seura, 2003).

Spector, Malcolm, and John I. Kitsuse, Constructing Social Problems, $2^{\text {nd }}$ ed. (New Brunswick, NJ: Transaction Publishers, 2001).

Tribe, Keith, Governing Economy: The Reformation of German Economic Discourse in 1750-1840 (Cambridge: Cambridge University Press, 1988).

Uljas, Päivi, Hyvinvointivaltion läpimurto: Pienviljelyhegemonian rapautumisen, kansalaisliikehdinnän ja poliittisen murroksen keskinäiset suhteet suomalaisessa yhteiskunnassa 1950-luvun loppuvuosina (Helsinki: Into, 2012).

Vauhkonen, Jussi, Elatuksesta eläkkeeseen: Vanhuudenturva suomalaisessa työnantajapolitiikassa työeläkejärjestelmän rakentamiseen saakka (Helsinki: Helsingin yliopisto, 2016). 